\title{
The Impact of Foreign Aid in Sustainable Development in Africa: A Case Study of Ethiopia
}

\author{
Kiros Abeselom \\ Wolaita Sodo University, Rural Development and Agricultural Extension, Wolaita Sodo, Ethiopia \\ Email: kiros.abeselom@wsu.edu.et
}

How to cite this paper: Abeselom, K. (2018). The Impact of Foreign Aid in Sustainable Development in Africa: A Case Study of Ethiopia. Open Journal of Political Science, 8, 365-422. https://doi.org/10.4236/ojps.2018.84026

Received: March 13, 2018

Accepted: September 7, 2018

Published: September 10, 2018

Copyright $\odot 2018$ by author and Scientific Research Publishing Inc. This work is licensed under the Creative Commons Attribution International License (CC BY 4.0).

http://creativecommons.org/licenses/by/4.0/

(c) (i) Open Access

\begin{abstract}
Foreign Development Aid Policy for the "underdeveloped areas" (Third World Countries) was announced by the former United States President Harry S. Truman on January 20, 1949. The overriding goal of this Foreign Development Aid Policy was supposed to "help people help themselves", i.e. help to self-help. But the practice or the reality on the ground of this Foreign Development Aid Policy shows clearly the opposite of help to self-help. Since this proclamation of the Foreign Development Aid Policy, thousands of Foreign Governmental and Non-Governmental Organizations are still engaged in "Development Aid Programs" in the Third World Countries for instance in the African countries like Ethiopia. Foreign Aid means, transfer of goods or services from one country to another country directly or indirectly for example bilateral from the United States of America to Ethiopia or through multi-lateral organizations such as the World Bank, the United Nations Organizations and many others. There are three different types of Foreign Aid. These are: 1) Military Aid, 2) Humanitarian Aid and 3) Official Development Assistance (ODA). ODA is the most common aid to Africa and it is more powerful economically than the other two. Therefore, the author of this research paper wants to investigate the impact of "Official Development Assistance" (ODA) in Sustainable Development in Africa: The Case of Ethiopia. However, there are three groups who argue pros and cons ("pro et contra") on the impact of the Foreign Aid in Sustainable Development in the Third World Countries in general and in Africa in particular, in the case of Ethiopia. Therefore, this Research Paper is interested to find out scientific evidences behind the controversial debates and discussions on the impact of the Foreign Development Aid Policy for Africa, in the case of Ethiopia.
\end{abstract}

\section{Keywords}

Foreign Development Aid Policy, Help to Self-Help, Pros and Cons, Scientific Evidences, Impact, Official Development Assistance 


\section{Introduction}

\subsection{Background}

Foreign Development ${ }^{1}$ Aid Policy for "underdeveloped areas", i.e. Third World Countries was announced by the former United States President Harry S. Truman. "Development Aid for underdeveloped areas" was one of his Four Point Speeches in his inaugural address on January 20, 1949. Truman said further: "We must embark on a bold new program for making the benefits of our scientific advances and industrial progress available for the improvement and growth of underdeveloped areas". ${ }^{2}$ Accordingly, the overriding goal of this Foreign Development Aid Policy was supposed to "help people help themselves", i.e. help to self-help.

Since this proclamation of the Foreign Development Aid Policy, thousands of Foreign Governmental and Non-Governmental Organizations are still engaged in "Development Aid Programs" in the Third World Countries for instance in the African countries like Ethiopia.

However, the practice or the reality of this "Foreign Development Aid Policy" on the ground is controversial. According to the literature this "Foreign Development Aid Policy" shows clearly the opposite of help to self-help in the African countries for example in Ethiopia. The author of this Research Paper is convinced by this critic, because this type of development aid continues to create dependence instead of self-help in the African countries for instance in Ethiopia. According to many scholars, the above mentioned "Foreign Development Aid Policy" creates more dependence not only Ethiopia but also other African countries like Uganda. "Critics argue that due to the foreign aid Uganda is more indebted today than ever before. It has been assessed that "approximately USD 3,100 million is owed to the multilateral creditors with World Bank, IMF, and African Development Bank being the main creditors" ${ }^{3}$

However, Ethiopia is affected by poverty and hunger which remain rife despite very fertile soil and decades of huge foreign development aid. In other words, paradoxically even the potential rich African countries, like Nigeria, the Democratic Republic of Congo, Angola, Ethiopia is still dependent on foreign food aid, although these countries are very rich in natural/mineral, agricultural and human resources. But unfortunately, many people in the other continents like in Europe or North America think that Africa is a small homogenous poor village. But fact is the continent of Africa has 55 independent countries and the total area is 30.3 Million $\mathrm{km}^{2}$ ( $22 \%$ of the earth) or three times bigger than Europa. Africa is the second largest continent in the world.

Marietta Slomka said that Africa is not poor, then it has breath-taking incredible landscape, almost inexhaustible important reserves of natural resources and fertile land (fertile soils) that Ethiopia alone could feed easily the whole conti-

${ }^{1}$ The term "Development" in international context encompasses the need and the means by which to provide better lives for people in poor countries.

${ }^{2}$ Truman, H. S. Library \& Museum

${ }^{3}$ Sanchez (2016): "Foreign Aid and Growth in Africa: a case study of Uganda", https://research-methodology.net/foreign-aid-and-growth-in-africa/ 
nent of Africa. ${ }^{4}$ Because Ethiopia is a big and very fertile land. Ethiopia is $10^{\text {th }}$ largest country $\left(1.133 .380 \mathrm{~km}^{2}\right)$ in Africa but more than three times bigger than Germany $\left(357.000 \mathrm{~km}^{2}\right)$ or as big as France and Spain together. Consequently, Slomka asks: "Who gets the benefit of the immense richness of the continent?"

Calestous Juma said about the fertile land of Ethiopia that [...] Ethiopia has more than 74 million hectares of cultivable land. So far, only 15 million is cultivated. Bringing three million hectares of land into cultivation in the coming four years is a modest step in the country's effort to foster economic transformation and does not represent misguided land allocation". ${ }^{5}$

Moreover, the New York Times report shows that Ethiopia has one of the most fertile lands in the African continent. It has the potential to become the "food basket of the world".

But it is also fact that Ethiopia is not in a position to feed its own citizens let alone to feed the whole citizens of the African continent. Volker Seitz said about the paradox of Africa that the continent has abundant resources which are almost unimaginable quantity and it has diverse cultures. He said: Africa is rich: $60 \%$ of world coffee, $70 \%$ of cacao, $50 \%$ of phosphate, $40 \%$ of plastinic come from Africa. The coltan is the rare kind of ore which exists only in Kivu at the border between Democratic Republic of Congo, Burundi and Rwanda/Uganda. Coltan is indispensable for the manufacturing of Mobil telephone, Laptops and steering system of rockets and or missiles and accordingly it is precious. Moreover, Africa has rich treasures of diamond, sapphire, (...), gold, petroleum, natural gas and last but not least roses (flowers) should be mentioned. Seitz said further that Africa has bad governance and it is mismanaged. The permanent receive of charity suffocates every initiative for self-help because "Foreign Development Aid" cements the dependency or immaturity of Africa. ${ }^{6}$ In addition to the above quoted facts the World Bank had published its report on October 24, 2012 about the capacity of the African continent under the title: "Africa Can Feed Itself, Earn Billions, and Avoid Food Crises by Unblocking Regional Food Trade" as follows: "A new World Bank report says that Africa's farmers can potentially grow enough food to feed the continent and avert future food crises if countries remove cross-border restrictions on the food trade within the region. According to the [World] Bank, the African continent would also generate an extra US \$20 billion in yearly earnings if African leaders can agree to dismantle trade barriers that blunt more regional dynamism. The report was released on the eve of an African Union (AU) ministerial summit in Addis Ababa on agriculture and trade." But the question is, why the World Bank has released a report about the potential capacity of the African continent just now (in 2012)? Was the potential capacity of the continent really new for the World Bank up to 2012?

Fact is, the World Bank was established in 1944 and therefore, the World

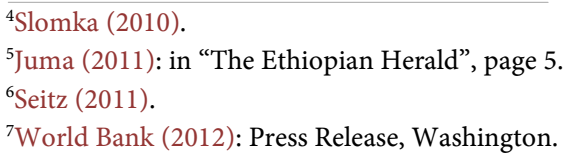


Bank should know about the potential capacity of the African continent before October 24, 2012. Another paradox situation of Africa shows as follows: “Africa's annual food import bill of $\$ 35$ billion [is], estimated to rise to $\$ 110$ billion by 2025, [that] weakens African economies, decimates its agriculture and exports jobs from the continent. Africa's annual food import bill of \$35 billion is just about the same amount it needs to close its power deficit." ${ }^{8}$ The African continent is not only potential rich but also real. Ellen Johnson Sirleaf, President of Liberia and Nobel Peace Prize Laureate said about the actual capacity of the continent as follows: “Africa loses at least $\$ 18$ billion a year because of conflicts. This is money our continent can ill afford to lose." According to the Mbeki-led report of the High Level Panel on Illicit Financial Flows Africa is estimated to have lost in excess of $\$ 1$ trillion over the last 50 years. ${ }^{10}$ This sum is roughly equivalent to all of the official development assistance received by Africa during the same timeframe. Currently, Africa is estimated to be losing more than $\$ 50$ billion annually in IFFs. ${ }^{11}$

"The Mbeki-led report of the High Level Panel on Illicit Financial Flows has carried out investigations across the regions since it was established in February 2012." "12 "Our continent is annually losing more than 50 billion US dollars through illicit financial outflows", remarked Mbeki reporting to the Pan African Parliament yesterday. "Our panel is convinced that Africa's retention of the capital that is generated on the continent and should legitimately be retained in Africa must be an important part of the resources to finance the Post-2015 Development Agenda."13 "According to this report, the flows relate principally to commercial transactions, tax evasion, criminal activities such as money laundering, and drugs, arms and human trafficking, bribery, corruption and abuse of office." 14

Also the Economic Commission for Africa said during the $30^{\text {th }}$ Assembly of Heads of State and Government holding from 22 - 29 January 2018 in the headquarter of the African Union in Addis Ababa, Ethiopia that over \$148 billion U.S. dollars are drained every year out of the African continent through various corrupt activities, representing about 25 percent of Africa's GDP growth. ${ }^{15}$ "The Executive Secretary of the United Nations Economic Commission for Africa (UNECA), Mrs. Vera Songwe, said on Thursday that the money was lost through various fraudulent activities, Songwa addressed the $32^{\text {nd }}$ ordinary session of the Executive Council of the African Union summit in Addis Ababa."16

Therefore, African Union (AU) has announced during its 30th Assembly of

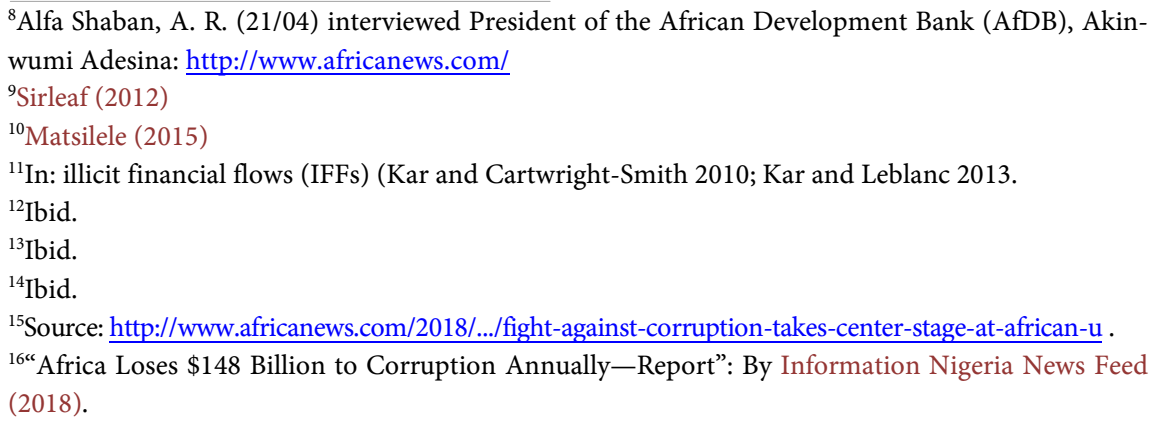


Heads of State and Government holding from 22 - 29 January 2018 in its headquarters in Addis Ababa that the African Union will Launch 2018 as the "African Anti-Corruption Year". The Summit of the AU was held under the theme: "Winning the Fight against Corruption: A Sustainable Path to Africa's Transformation". ${ }^{17}$

However, the question is, who will fight against corruption? The answer is logically, those who are not involved in corruption. But who are they? How many are they?

This slogan "2018 as the "African Anti-Corruption Year" may remain at the end only as a "paper tiger".

As already stated above, the purpose of the "Foreign Development Aid Policy" which was proclaimed by the Ex-President Harry S. Truman on January 20, 1949 was supposed to "help people help themselves", i.e. help to self-help. Since this proclamation, thousands of Foreign Governmental and Non-Governmental Organizations are still engaged in "Development Aid Programs" in the Third World Countries for instance in the African countries like in Ethiopia.

However, the question is: If Africa loses 148 billion U.S. dollars annually, for what purpose needs Africa Foreign Development Aid?

The other question is, what does Foreign Development Aid mean for the Third World Countries for example for the African countries like Ethiopia?

According to the literature: "Foreign aid can be defined as 'any action by a government or citizen of one country, which helps to promote economic development in another country."' 18

According to other scholars, "Foreign Aid" means, transfer of goods or services from one country to another country directly or indirectly for example bilateral aid from the United States of America to Ethiopia or through multi-lateral organizations such as the World Bank, the United Nations Organizations and many others.

Therefore, the question is, what kind of goods or services are transferring?

Who transfers goods or services and from where to where?

Do the Western countries transfer goods and/or services for example to Africa or Africa transfers goods and/or services to the Western countries?

How much the Western world transfers goods and/or services to Africa comparing to that Africa transfers to the Western world?

\section{Who helps whom?}

In order to answer such questions, the author of this Research Paper wants to investigate the impact of the "Foreign Development Aid Policy" ("Official Development Assistance"/ODA) especially the role of Foreign Governmental and Non-Governmental Organizations in sustainable development in Africa, the case of Ethiopia.

According to George B.N. Ayittey there are three types of foreign aid:

${ }^{17}$ Tankou (2018): Head of Information Division: African Union Commission, E-mail: yamboue@africa-union.org

${ }^{18}$ Sanchez (2016): "Foreign Aid and Growth in Africa: a case study of Uganda". 
- humanitarian relief aid, given to victims of natural disasters such as earthquakes, cyclones and floods;

- military aid; and

- economic development assistance.

"Much confusion surrounds the third, also known as official development assistance or ODA. Contrary to popular misconceptions, ODA is not "free."19

"ODA is the most common aid to Africa and it is more powerful economically than the other two. [...] Official development assistance is defined by the Organisation for Economic Co-operation and Development (OECD) as concessional funding given to developing countries and to multilateral institutions primarily for the purpose of promoting welfare and economic development in the recipient country." 20

However, the question is, what are the real reasons and motives for the Foreign Aid?

"A twentieth-century innovation, foreign aid has become a familiar and even expected element in international relations. But scholars and government officials continue to debate why countries provide it: some claim that it is primarily a tool of diplomacy, some argue that it is largely intended to support development in poor countries, and still others point out its myriad newer uses. Carol Lancaster effectively puts this dispute to rest here by providing the most comprehensive answer yet to the question of why governments give foreign aid. She argues that because of domestic politics in aid-giving countries, it has always been-and will continue to be-used to achieve a mixture of different goals." 21

According to the literature, there are three groups who argue pros and cons ("pro et contra") on the effects of Foreign Aid in Sustainable Development in the Third World Countries in general and in Africa in particular.

One of the groups who argues against the current practices of the "Foreign Development Aid Policy", i.e. the "Official Development Assistance" (ODA) on the ground comprises academicians and public mass media.

\section{Here are the Three Groups as follows:}

\section{Group I:}

1) Brigitte Erler: describes the "Foreign Aid" (ODA) for the Third World Countries as deadly aid. ${ }^{22}$

2) James Shikwati says: "Stop Foreign Aid (ODA), it is killing Africa." He said further: "Who wants help Africa may not give money." Therefore, he advocates for cessation of the "Foreign Aid" immediately. Because, he said, the African states must learn to stand on their own feet. ${ }^{23}$

There are many more experts who criticize such Foreign Aid like for example

\footnotetext{
${ }^{19}$ Ayittey (1992): “THE MYTH OF FOREIGN AID”.

${ }^{20}$ Historpedia: Africa and Foreign Aid (2012) https://sites.google.com.

${ }^{21}$ Lancaster (2008): “Foreign Aid: Diplomacy, Development, Domestic Politics”, University of Chicago Press.

${ }^{22}$ Erler (1985): “Tödliche Hilfe”, Freiburg.

${ }^{23}$ Shikwati (2007): "Entwicklungshilfe in der Kritik"/“Development Aid in the criticism", in: "n-tv" POLITIK", and in Internet.
} 
Dambisa Moyo who describes Foreign Aid in Africa in her book as "Dead Aid".

3) "Dambisa Moyo's book "Dead Aid" reveals why millions are actually poorer because of aid, unable to escape corruption and reduced, in the West's eyes, to a childlike state of beggary. We all want to help. Over the past fifty years $\$ 1$ trillion of development aid has flowed from Western governments to Africa, ${ }^{24}$ with rock stars and actors campaigning for more. But this has not helped Africa. It has ruined it." 25

4) Edrine Habasa and Nathan Andrews describe the impact of foreign aid in Africa in their articles as follows: Habasa says: "Foreign aid is a modern joystick used to play a modern game called the African economy! Have African economies been hijacked? It is an undeniable fact that foreign aid has extensively, intensively and forwardly steered the economies in Africa's countries."26

Andrews asks under the title: "Foreign aid and development in Africa" as follows: "Foreign aid and development in Africa: What the literature says and what the reality is". ${ }^{27}$

5) Also the West German Broadcasting Corporation (WDR) had described Foreign Aid for Africa under the title: "Fatale Entwicklungshilfe für Afrika" als "Süßes Gift" (as “disastrous aid for Africa-sweet poison"). ${ }^{28}$

The above mentioned critics are against the "Foreign Development Aid Policy" (ODA) because the current practices of this Development Aid Policy continues to create more dependence instead of self-sufficiency in the Third World Countries for instance in the African countries. ${ }^{29}$ One country affected is Ethiopia, where poverty and hunger remain rife despite very fertile soil as well as the engagements of thousands of governmental and non-governmental local as well as foreign organizations since 1961.

Group II: This Group wants "Deadline Set to End Foreign Aid Dependence"

One of the advocators of setting a "solid deadline on which the country will stop depending on foreign aid" is President Paul Kagame of Rwanda. "Rwanda President Paul Kagame has asked members of his government at the $14^{\text {th }} \mathrm{Na}$ tional Umushyikirano Council to set a solid deadline on which the country will stop depending on foreign aid. President Kagame said it is high time they responded to the issue they have been discussing for a long time; "The issue of relying on others to pay for things that benefit us. It is really a question of dignity...our Agaciro." He wants this Dialogue to set a timeline for an end to Rwanda's dependence on aid." 30

${ }^{24}$ Sanchez (2016): "Foreign Aid and Growth in Africa: a case study of Uganda”. "According to Wall Street Journal (2009), over the past 60 years the amount of foreign aid provided to Africa has exceeded USD 1 trillion.”

${ }^{25}$ Moyo (2009): “Dead Aid”, New York.

${ }^{26}$ Habasa (2015)

${ }^{27}$ Andrews (2009) Vol. 1(1) pp. 008-015

${ }^{28}$ WDR (2012): “West Art” "Fatale Entwicklungshilfe für Afrika” als “Süßes Gift"

${ }^{29}$ “Today African countries are more dependent on foreign aid than they have ever been." Source: Historpedia: Africa and Foreign Aid (2012) https://sites.google.com 
Here is the $3^{\text {rd }}$ group who argues in favour of "Foreign Development Aid" for the Third World Countries for instance for the African countries.

\section{Group III: This Group comprises as follows:}

- All governments especially of the western world and the majority of governments of the "Aid" recipient countries,

- International Governmental and Non-Governmental Organizations like the World Bank, the United Nations Organizations, and

- Prominent figures or personalities from the western world who support Foreign Aid Policy for the Third World Countries.

For example, governments of the western world:

1) Jon Benjamin from United Kingdom Foreign \& Commonwealth Office: supports foreign aid in his speech on "Foreign Aid Impact on Africa's Development" as follows: "Whether foreign aid works has been polarized between the 'Oh yes it does' camp and those who respond 'Oh no it doesn't.' That's too simplistic a juxtaposition. Some might say that the fact that we are still asking this most basic question about aid over 60 years since official aid started to flow in the late 1940s is an indication of how relatively little we sometimes seem to know about aid's impact and influence. In the UK, we don't however have such existentialist doubts. The UK alone amongst the world's largest economies has reached the UN target of giving $0.7 \%$ of GNI in overseas development assistance (ODA). That's around $£ 12$ bn this year of UK aid worldwide, or getting on for US $\$ 20 \mathrm{bn}$, which means about half the size of Ghana's whole economy. [...] Why do we do this? Because we believe it's the right thing to do, both morally as a good global citizen and, in this case, because of the responsibilities we take from our own history and colonial involvement in Africa." ${ }^{31}$

2) Also Charles Abugre supports Foreign Aid due to ethical aspects as follows: He asks: "Why foreign aid is important for Africa: The idea that those who have should share with those who don't is inherent in most societies-insects, animals and humans alike. Sharing is essential to maintain and protect the collective, and empathy is an essential value of what it is to be human. It is inhuman to watch another dying of hunger and not share when you have more than enough to eat. International aid is the instrument by which this very human practice occurs in modern times across borders, and should ordinarily not be controversial. But it is-very much so. Food aid is the root of the international aid system, although it represents only a small proportion of total aid (three to five percent). Thanks to international emergency response, famines and other natural and human-made disasters no longer kill in the numbers they used to prior to the 1980s. Food aid saves lives in emergencies but can also create dependencies by destroying local farming capacities when food aid becomes food "dumped" on

${ }^{30} \mathrm{McDoom}$ (2013):

https://unu.edu/publications/articles/to-aid-or-not-to-aid-the-case-of-rwanda.html; Dickinson (2009): Kagame: "Foreign aid on our terms: Writing in the Financial Times".

${ }^{31}$ Benjamin (2015) 
the local market." ${ }^{\prime 2}$

As already stated above, this group justifies its support for the Foreign Aid Policy due to humanitarian or ethical aspect. However, this Research Paper focuses on the Official Development Assistance (ODA) and the debates and discussions on the effects of Foreign Aid Policy for instance in Africa which is supposed primarily for the purpose of promoting welfare and economic development in the recipient countries. Because humanitarian aid or food aid is not debatable if it is done in a sincere or genuine way, i.e. without self-interest (altruistic).

Therefore, the criticisms are not against the general Foreign Development Aid principles but against the current practices of the Foreign Aid Policy on the ground for instance in the African countries like in Ethiopia.

Accordingly, the author of this Research Paper supports the critics of the current Foreign Aid Policy practice on the ground because today African countries are more dependent on foreign aid although they are rich in natural/mineral, agricultural and human resources.

However, the Foreign Development Aid Policy is not alone to blame for the dependency of the African countries for example in Ethiopia but also the governments as well as the societies in the African countries are responsible.

In order to find out scientific facts about the above stated controversial debates on the effects of the current Foreign Aid Policy in Africa for instance in Ethiopia, the author of this Research Paper has applied the following methodologies:

1) Various sources like historical and present publications are reviewed.

2) Two different locations and study areas are selected as case study (empirical and observation). These are Ambo District (western Ethiopia). Ambo is about $114 \mathrm{~km}$ far away from Addis Ababa. The other districts are Ijaji/Bako, Mendi, Ghimbi, Nejo (western part of Ethiopia). All these districts are in Oromia State Region in western Ethiopia. The next location is Nekemte, the capital city of Wollega/Oromia State Region in western Ethiopia. Another study area is Asosa (the capital city of Benshangul Gumuz/Regional State of western Ethiopia). Asosa is 476 kilometers ( 296 miles) far away from Addis Ababa.

Therefore, this researcher paper would like to demonstrate the situation of Ethiopia by selecting these different locations and study areas that Ethiopia could be in a position not only to feed its citizens but also to export cereals, fruits and vegetables to other countries. In order to make more clear the paradox situation of Ethiopia, two case studies (empirical studies and observations) were conducted in the above selected different locations and study areas, i.e. one empirical study or observation was Awaro (Gerimelke: the name of a farming area for different crops) in Ambo District. The other case study was in the above mentioned selected areas which have different fruit plantations like mango, avocado, banana as well as coffee plantations.

${ }^{32}$ Abugre (2010) Special to CNN. 
Hence, the objective of this Research Paper is to examine the paradox situation of Africa as an example of Ethiopia but also Nigeria, Democratic Republic of Congo (DRC) because these countries are rich in natural/mineral, agricultural and human resources on one hand but they are poor on the other hand.

Last but not least, the researcher of this Research Paper would like to discuss on the role of China's involvement in Sustainable Development Aid in Africa, a case study of Ethiopia. According to the literature China and India are re-emerging donors to Ethiopia and Africa, at least as long as the West. "However, until recently the aid flow from both countries was very minimal, which is unlike the aid from western countries". ${ }^{33}$

"Ethiopia's main objectives for allowing Chinese investment to operate in country are to have access to high technology, to increase employment, to acquire know-how, to increase foreign exchange through export, and to benefit from both backward and forward linkages." ${ }^{34}$

"China has been providing aid to the best of its ability to other developing countries with economic difficulties, and fulfilling its due international obligations." 35

However the question is, what are the differences between the "Development Aid Policies" of the Western world on one hand and of China and India on the other hand?

According to the literature, the Chinese government held in August 2010 the "National Conference on Foreign Aid to summarize its experience of foreign aid work, and define the major tasks for strengthening and improving foreign aid in new circumstances. China's foreign aid thus entered a new stage." ${ }^{\text {36 }}$

What are the Basic Features of China's Foreign Aid Policy for instance towards Africa?

Some Basic Features of China's Foreign Aid Policy are as follows:

- "Unremittingly helping recipient countries build up their self-development capacity. Practice has proved that a country's development depends mainly on its own strength. In providing foreign aid, China does its best to help recipient countries to foster local personnel and technical forces, build infrastructure, and develop and use domestic resources, so as to lay a foundation for future development and embarkation on the road of self-reliance and independent development.

- Imposing no political conditions. China upholds the Five Principles of Peaceful Coexistence, respects recipient countries' right to independently select their own path and model of development, and believes that every coun-

\footnotetext{
${ }^{33}$ Jalata (2014): "Development Assistance from the South: Comparative Analysis of Chinese and Indian to Ethiopia", in: Chinese Studies 2014, Vol. 3, No.1, Published Online.

${ }^{34}$ Desta (2009): “Chinese Investment in Ethiopia: Developmental Opportunity or Deepening China's New Mercantilism?”

${ }^{35}$ Source: China's Foreign Aid (2011): Information Office of the State Council: The People's Republic of China.

${ }^{36}$ Foreign Aid Policy-China.org.cn (2011):

http://www.china.org.cn/government/whitepaper/2011-04/21/content_22410897.htm
} 
try should explore a development path suitable to its actual conditions. China never uses foreign aid as a means to interfere in recipient countries' internal affairs or seek political privileges for itself.

- Adhering to equality, mutual benefit and common development. China maintains that foreign aid is mutual help between developing countries, focuses on practical effects, accommodates recipient countries' interests, and strives to promote friendly bilateral relations and mutual benefit through economic and technical cooperation with other developing countries."37

As stated above the China's Foreign Development Aid Policy is based on help to self-help, Mutual Respect and Mutual Benefit. These principles are key elements of China's Foreign Policy and even smaller African countries with relatively little economic or political significance have received relatively large aid and investment support from China. [...] "At the onset, China's aid policy was premised on equality between partners, mutual benefit, respect for sovereignty, respect for obligations and enhancing the self-reliance of Chinese aid recipients." 38

This means that China's Foreign Development Aid Policy is different to the Foreign Development Aid Policy of the Western world.

\subsection{Statement of the Problem}

The reasons why the researcher wants to write this research paper are the social, economic, and environmental problems of the Third World Countries in general and the paradox situation of the African in particular. For example, Ethiopia but also Nigeria, Democratic Republic of Congo (DRC) are rich in natural/mineral, agricultural and human resources on one hand but they are also poor on the other hand. They are even dependent on foreign food aid. Although Nigeria is currently the richest country in Africa it is depend on foreign food aid.

If we take for example the DRC as already described in this Research Paper it is widely considered to be the richest country in the world regarding natural and agricultural resources; its untapped deposits of raw minerals are estimated to be worth in excess of US \$ 24 trillion. ${ }^{39}$ But currently the DRC "is one of the poorest countries in the world." ${ }^{\prime 0}$

Marietta Slomka said that Africa is not poor, then it has breath-taking incredible landscape, almost inexhaustible important reserves of natural resources and fertile land (fertile soils) that Ethiopia alone could feed easily the whole continent of Africa.

For instance, the DRC is the second largest country in Africa. The DRC covers a land area larger than the combined areas of Spain, France, Germany, Sweden, and Norway with a population about 77 million. But currently the DRC "is one of the poorest countries in the world?" However, the DRC is widely considered ${ }^{37}$ Jalata (2014): "Development Assistance from the South: Comparative Analysis of Chinese and Indian to Ethiopia”, Chinese Studies-Scientific Research Publishing, Vol. 03 No. 01.

${ }^{38}$ Ibid.

${ }^{39}$ Source Internet.

${ }^{40}$ WHO (19.01.2015): Source: Internet. 
to be the richest country in the world regarding natural and agricultural resources; its untapped deposits of raw minerals are estimated to be worth in excess of US \$ 24 trillion. “The Congo [DRC] is the world's largest producer of cobalt ore and a major producer of copper and diamonds. The Congo has 70\% of the world's coltan, a third of its cobalt, more than $30 \%$ of its diamond reserves, and a tenth of its copper. [...] The Mining industry of the Democratic Republic of the Congo is a significant factor in the world's production of cobalt, copper, diamond, tantalum, tin, and gold as well. [...] A combination of such highly sought resources and recent political struggles have made the Central African nation one of the most affected by the illegal exploitation of its resources. [...] Although the DRC is extremely rich in natural resources, this country is politically unstable, i.e. civil war waged.

That is why Slomka asks "who gets the benefit of the richness of the African continent"?

Another question is, what are the causes of this paradox situation of the African countries like Ethiopia, Nigeria, Democratic Republic of Congo (DRC), etc.?

As already discussed in this Research Paper the paradox situation of the African countries like Ethiopia, Nigeria, Democratic Republic of Congo (DRC), etc. has "exogenous" as well as "endogenous" causes. The author of this Research Paper would like to forward the following two hypotheses for further discussions on the possible causes of the paradox situation of the African countries like Ethiopia, Nigeria, Democratic Republic of Congo (DRC), etc.

Firstly, the European colonization but especially the influence of the colonists on the mentality of the colonies could be the beginning of the dependent mentality (thinking) or expecting from others, i.e. from the European colonists.

Secondly, during this unstable (dependency) situation of the colonies "Foreign Development Aid Policy" had cemented or solidified deeply the dependent mentality of the colonies up to now. However, the colonies were not in a position during the colonial era to develop independent mentality because their resources especially human resource (educational building capacity) was not matured in quality as well as quantity. But today the natural/mineral, agricultural and human resources of the "former" colonies like Ethiopia, Nigeria, Democratic Republic of Congo (DRC), etc. are matured.

But despite this reality these countries are still dependent on their colonists like in the colonial era.

Therefore, these countries like Ethiopia, Nigeria, Democratic Republic of Congo (DRC), etc. are responsible for continuous dependent on foreign aid especially on food security today. These are the reasons why the author of this Research Paper argues that the causes of the paradox situation of the African countries have "exogenous" as well as "endogenous" factors.

However, the question is, what could be the alternative solutions for the economic, social, political and environmental problems of the African countries like Ethiopia, Nigeria, Democratic Republic of Congo (DRC), etc.? In other words, 
how do these countries manage to come out of the paradox situation or vicious circle, i.e. dependency? In order to solve such paradox situation the responsibilities at the top of the management and the whole society should have visions, objectives (aims), responsibilities, accountabilities, Law and Order and ethical principles.

If the African elites are committed for change or to be independent and to solve poverty, the researcher of this paper believes that the following ethical principles are factors or criteria of development of the African continent if the top management of the African countries like Ethiopia, Nigeria, Democratic Republic of Congo (DRC), etc. implements the following ethical principles: Integrity, Loyalty, Transparency, Confidentiality, Honesty, Accountability, Priority to interest of the public, Exercising legitimate Authority, Impartiality, Respecting the law, Responsiveness, Exercising leadership.

However, despite all these realities many academicians or scholars, governments, international organizations and mass media in the Western world but also the elites in the Third World Countries for example in the African countries propagate birth control as the solution for the economic, social, political and environmental problems for example of the African countries like Ethiopia, Nigeria, Democratic Republic of Congo (DRC), etc. As already discussed in this Research Paper about the Malthusian and Neo-Malthusian hypothesis which says population growth is the cause for economic, social and environmental problems in the Third World Countries, especially in Africa as an example of Ethiopia, the solution of these problems is for the Malthusians and Neo-Malthusians birth control but as they call it "family planning". This unproved hypothesis is advocated by many academicians or scholars and organizations like for example the United States Agency for International Development (USAID), German International Cooperation (GIZ), United Nations Fund for Population Activities (UNFPA), World Bank, German Foundation for World Population /DSW/ (Deutsche Stiftung Weltbevölkerung), DKT-Ethiopia, many mass media in the Western world but also by the elites in the Third World Countries for instance in the African countries.

For USAID ${ }^{41}$, German Federal Foreign Office (Auswärtiges Amt) and the GIZ "22 "rapid population growth" in Ethiopia is the cause of poverty and environmental problems for instance for soil erosion and hindrance for economic growth. ${ }^{43}$

Although the causes of poverty and dependence on foreign aid in Africa are known as noted above, many organizations, governments and the media in the Western world but also the elite in the African countries argue that poverty and food insecurity are caused by "rapid population growth" in the African countries

\footnotetext{
${ }^{41}$ Source: "Evolution of USAID Development Priorities in Ethiopia"-US Agency for... https://www.usaid.gov/

${ }^{42}$ Source: GIZ: Äthiopien-https://www.giz.de/de/weltweit

${ }^{43}$ German Federal Foreign Office/Deutsches Auswärtige Amt (2013): Wirtschaft Äthiopiens, Stand: März 2013 and GIZ: Äthiopien-https://www.giz.de/de/weltweit
} 
for example in Ethiopia. But with their hypothesis they represent the opinion of the Malthusian and Neo-Malthusian hypothesis which says: population growth causes economic, social, political unrest and environmental problems.

As already noted above Thomas Robert Malthus had published his Essay on Population Growth impact on economic and social problems in England (1798). He argued in his Essay that population multiplies geometrically and food arithmetically; therefore, the population will eventually outstrip the food supply. However, this hypothesis of Malthus was not realized neither in the UK nor in other Western countries. But the followers of Malthus, i.e. the Neo-Malthusians say that the hypothesis of Malthus happens in the Third World Countries today. The Neo-Malthusians try to bring extreme situations as an evidence for their hypothesis, for instance, the famine in Ethiopia in 1984/85, droughts and other environmental problems.

Therefore, the researcher of this Research Paper would like to discuss on the real causes of poverty and food insecurity in Africa in general but in Ethiopia in particular. Therefore, this Research Paper would like to conduct the research on the basis of theoretical and practical significance and to find out scientific facts behind the controversial debates and discussions on the real causes of the economic, social and environmental problems in Ethiopia.

Accordingly, the researcher of this Research Paper is interested:

Firstly, to investigate the impact of "Foreign Development Aid Policy" for Africa in the case of Ethiopia.

Secondly, to prove or disprove the Malthusian and Neo-Malthusian hypothesis on the reality on the ground. ${ }^{44}$

As already discussed above the paradox situation of the African countries like Ethiopia, Nigeria, Democratic Republic of Congo (DRC), etc. has "exogenous" as well as "endogenous" causes. Therefore, the "Foreign Development Aid Policy" and/or the Foreign Governmental and Non-Governmental Organizations are not to blame alone for continuous dependency and the paralysis situation in Africa for example in Ethiopia but also the responsible governments as well as the societies in the African countries for example in Ethiopia.

As the Ethiopian Federal Auditor General Report shows recently financial irregularities by 158 federal institutions of Ethiopia and the accusation of the Ethiopian Federal Attorney General against more than 50 higher government officials which were arrested in July 2017 for suspected of corruption are good examples for "endogenous" factors that how governmental institutions are damaging their own country in billions of USDs. The state media (Ethiopian Broadcasting Corporation/ETV) has quoted the Federal Auditor General in June 2017, that 5.3 billion Birr fraud by 158 federal institutions and 28 branches (among them 27 public universities) through unnecessary expenditures, unaccounted expenses, uncollected revenues and overuses of the budget. Therefore,

${ }^{44}$ Abeselom (2017): "The reasons behind the debates and discussions on population growth: Positive or negative impacts on economic, social, political, natural resources and environmental developments". 
corruption is the evil of development and the cause of poverty as well as dependence of the African countries for instance of Ethiopia.

One of the reasons of the paradox situation of Africa is that begging is easier for many governments and also many societies in Africa than to make efforts in order to be independent from aid. Because dependency has negative impacts on psychological, political, economic, social, and cultural developments in the African countries as an example in Ethiopia. This is an example of "exogenous" cause of the paradox situation of the African countries like Ethiopia, Nigeria, Democratic Republic of Congo (DRC), etc.

However, the researcher of this Research Paper is convinced that mismanagement of these huge resources of Ethiopia is the barrier of development as the following examples show: Human resource, Fertile land (agricultural products), Historical places for tourist attraction, Coffee, Tea, Oil seeds, Fruits, Vegetables, Spices, etc. could be as Export Hit or Leading Export article for Ethiopia.

In addition to the above mentioned resources Ethiopia has abundant natural resources, such as gas, minerals like salt, renewable resources like solar energy ("13 month of sunshine"), wind energy, water, According to the literature Ethiopia has too many rivers and lakes to count (see below some examples).

1) Water is an important natural resource. Ethiopia has the longest river in the world, the Blue Nile River. Ethiopia has 12 river basins that give the potential for hydro power and irrigation but unfortunately there is no irrigation system in the country as it should be. But there are more natural (renewable) resources which could be applied for the development of this country, for example:

2) Solar Energy ("13 month of sunshine"), Wind Energy, Biogas/biomass, Thermal Energy,

3) Four different climate zones (Air: Climate is unpolluted in so many ways), etc.,

4) National parks,

5) Huge livestock: But nobody takes care of them for example concerning health care, feeding, against smuggling out of the country, etc.

But despite all these and other resources of the country Ethiopia is one of the poorest countries in the world and it depends on foreign food aid because its huge resources are not: Organized, Coordinated, Planned and Prepared. Therefore, the question is again, what are the causes of this paradox situation of this country and what are the alternative solutions to come out from this vicious circle?

The researcher of this Research Paper is convinced that some "Development Factors" should come first in order to solve such problems.

These are for example:

1) Responsibility (Charge):

Let us take the problem of the fall armyworm in 2017 as example which has destroyed maize fields in hundred thousands of hectares in 6 maize growing regions of Ethiopia. "The fall armyworm, which first arrived in Africa in 2016, was intercepted on a few hectares of irrigated maize fields in southern Ethiopia in the 
last week of February 2017. It has now covered about 52,962 hectares in 144 districts in three of the major maize-growing regional states-Gambella, Oromia and Southern Nations Nationalities and Peoples' Region (SNNPR)." ${ }^{45}$

According to the opinion of the researcher of this paper the following institutions have responsibilities to prevent the crops for example from the damage of the armyworm:

- Ethiopian Ministry of Agriculture and Natural Resources

- Federal Research Institutes of Agriculture

- Regional State Bureaus of Agriculture

- Food and Agriculture Organization of the United Nations (FAO), World Bank, United Nations Development Programme (UNDP), UN-World Food Program (WFP), USAID, GIZ, UNFPA, etc.

- Ethiopian Universities like for example: Haramaya University (oldest and biggest for Agriculture), Ambo University, Jimma University, Mekele University, Hawassa University, etc.

Therefore, the question is, where are the early warning systems of the above mentioned institutions as well as the researchers of the universities in Ethiopia?

\section{2) Accountability}

Under the title "Audit report irks lawmakers"46 shows the following Federal Auditor Report that there is accountability and control in the governmental institutions in their annual unnecessary expenditures. The Ethiopian Federal Auditor General Gemechu Dubiso had presented his annual report to the parliament in June 2017. "The Auditor General, in its latest report, revealed illegitimate transactions close to 20 billion $\mathrm{Br}$ [Birr] in 158 federal institutions during the past fiscal year-over twice that of the gap seen in 2014/15. This was announced when the Auditor General presented its report of government institutions to the Parliament on May 30, 2017."

A newspaper quoted the Ethiopian Federal Auditor General Gemechu Dubiso under the title "Ethiopia: Audit Gaps Surge, Parliament Condemns Itself" 48 as follows: "The 57-page brief summary report highlighted unnecessary expenditures, unaccounted expenses, uncollected revenues and overuses of the budget by the institutions. In the report, Gemechu Dubiso, the Auditor General, said that 53 institutions had serious audit gaps last year, an increase from 37 in 2014/15. He also indicated most of the institutions were unable to explain why so much money was inappropriately spent.

With an audit gap of 3.7 billion $\mathrm{Br}$ [Birr], public universities were a hot topic of discussion. [...] Among the public universities, Addis Ababa University (AAU) took the lead with an audit gap of 1.2 billion $\mathrm{Br}$ [Birr].

The complaints come on the heels of the Auditor General's report on the 2008... same reports of repeated financial irregularities by federal institutions....

${ }^{45}$ Source: Xinhua (2017/6/15): Ethiopian Ministry of Agriculture and Natural Resources, Ethiopian Broadcasting Corporation (2017) and Internet.

46“The REPORTER" (05.06.2017) by Abiye (2017).

${ }^{47}$ Ibid.

48“Addis Fortune" (04.06.2017), by Hailemeskel (2017). 
on the Auditor General's report last year, Tesfaye urged the government to... to the tune of 5.3 billion birr was found at 113 institutions and 28 branches. "This shows how the situation is getting worse and worse every year," said one of the parliamentarians, referring to the successive reports.

"There is a serious lack of accountability," said Gemechu. "Most of them tend to work against the law of the land." [...] "Members of the House of People's Representatives (HPR) on Tuesday expressed frustration over most federal government institutions for their financial irregularities. The complaints come on the heels of the Auditor General's report on the 2008 E.C. fiscal year budget utilization.

Mulu Gebregziabher, one of the few outspoken MPs, hailed the Auditor General for his commitment in presenting very "critical" reports, as he has been doing over the past several years. She, however, said she is sick and tired of listening to the same reports of repeated financial irregularities by federal institutions. MPs also told House Speaker Abadula Gemeda that the house should take stricter action wrongdoing institutions in accordance with the duties and responsibilities vested upon it by the constitution." 49

Another paradox of this country shows that the country's Parliament has deliberated the budget for 201/2018 as 320.8 billion Birr ${ }^{50}$ versus 5.3 billion Birr Fraud by Ethiopian Federal Governmental Institutions as already explained above. $^{51}$

Although the Ethiopian government needs money to solve its huge problems, some Ethiopian Federal Governmental Institutions like the ETHIOPIAN ELECTRIC POWER CORPORATION (EEPCO) do not collect bills in time when customers come to these Institutions to pay their bill. One of the reasons is "lack of invoice and/or receipt". Unfortunately, EEPCO repeats this kind of reason many times at different areas of the country. ${ }^{52}$ The Ethiopian Parliament criticized recently the EEPCO for failing to collect bills in millions of birr from customers. $^{53}$

Therefore, the question is, why a poor country like Ethiopia or its government doesn't need money and why this big federal institution (EEPCO) couldn't solve such silly problem, i.e. for example to provide invoice and/or receipt for the customers?

The above noted examples are some of the Development Barriers of Ethiopia.

\section{Development Barriers of a Country}

What are the other political, economic, social and ecological barriers of development of a country like for example Ethiopia?

The researcher of this Research Paper is convinced that, the following factors are barriers of development of a country like Ethiopia: War or political and so${ }^{49}$ Ibid.

${ }^{50}$ Source: Ethiopian Broadcasting Corporation (2017).

${ }^{51}$ One US Dollar equals 23.26 Ethiopian Birr (on 13.07.2017).

${ }^{52}$ The author of this Research Paper has observed such problems of EEPCO offices in Ambo town (2015-2016) and Wolaita Sodo town (2017).

${ }^{53}$ Source: Ethiopian Broadcasting Corporation news on 18.01.2018. 
cial unrest, Irresponsibility, Not accountability, Intolerance, Uncommon Understanding and Common Aim among the society of a country, Dishonesty (Not sincerity), Un-justice, Un-fairness, Un-Openness (Not sincerity), Mistrust (Not confidence), Un-reliant, Not-transparent, Undisciplined. Despite all these facts, the Ethiopian government and international Non-Governmental Organizations for example the German Foundation for World Population (Deutsche Stiftung Weltbevölkerung), DKT-Ethiopia etc. focus only on birth control to solve poverty and these development barriers?

But which one is easier and better: To avoid these barriers or the birth of a child?

Who told the Ethiopian government that birth control is the solution to solve poverty and corruptions as well as rent seeking of the society?

As already stated in this Research Paper thousands of foreign Governmental and Non-Governmental Organizations are still engaged in "Development Aid Programs" in the Third World Countries for instance in the African countries like Ethiopia since the proclamation of the "Foreign Development Aid Policy" by the former United States President Harry S. Truman on January 20, 1949.

However, the question is how many Governmental and Non-Governmental Organizations are engaged in humanitarian and development aid in Ethiopia ${ }^{54}$ ?

According to the Ethiopian Authority for Early Warning Disaster Risk Monitoring and Response in the year 2011 there were about 2000 international and local Relief and Development Aid Organizations in Ethiopia. ${ }^{55}$ But Owen Barder said that: "There are about 3800 NGOs here in Addis [Ababa/Ethiopia], with a total budget of $\$ 1.5$ billion a year. That is a lot of money in a country in which the annual government budget is about $\$ 4$ billion a year." ${ }^{\prime 26}$

Another report shows that the number of international civil society groups or NGOs who were 2012 operating in Ethiopia were about $3000 .^{57}$

Anyway, the following Multilateral and Bilateral Organizations are operating currently (2016/2017) in Ethiopia. For instance the United Nations Organization (UNO) alone has the following agencies in Ethiopia:

1) UNDP-United Nations Development Programme

2) United Nations Fund for Population Activities (UNFPA)

3) United Nations Environmental Programme (UNEP)

4) UNIDO-United Nations Industrial Development Organization

5) United Nations International Children's Emergency Fund (UNICEF)

6) United Nations Education, Science and Cultural Organization (UNESCO)

7) United Nations Higher Commission for Refugee (UNHCR)

8) UN-Economic commission for Africa (UNECA)

9) UN-World Food Program (WFP)

10) UN-Capital Development Fund (UNCDF)

${ }^{54}$ More than 3000 Governmental and Non-Governmental Organizations were engaged in Ethiopia in 2017. Source: Ethiopian Broadcasting Corporation (EBC) news.

${ }^{55}$ Source: interview (2011) by the researcher of this paper.

${ }^{56}$ Barder (2009): “Aid effectiveness, Development, NGOs, Politics”, Addis Ababa.

57“Sudan Tribune” (2012): Source: Internet. 
11) UN-World Health Organization (WHO)

12) UN-Food and Agricultural Organization (FAO)

13) United Nations Conference on Trade and Development (UNCTDA)

Also the European Union (EU) and the World Bank are present in Ethiopia.

\section{Moreover:}

- International Monetary Fund (IMF)

- International Fund For Agricultural Development (IFAD)

- African Development Bank (ADB) is also involved in Development Aid Programme in Ethiopia.

\section{Foreign Governmental and Non-Governmental Organizations in Ethiopia} From the United States of America (USA):

The United States Agency for International Development (USAID) is the biggest foreign organization in Ethiopia, CARE [Ethiopia], Catholic Relief Services, World Vision, Save the Children, DKT Ethiopia, Action Aid Ethiopia.

According to the report of the Global Development Research Center (1999) CARE [Ethiopia], Catholic Relief Services, World Vision, and Save the Children are United States-based examples of the larger international relief and development groups carrying out programs in the country [Ethiopia].

However, the United States Agency for International Development (USAID) is the biggest foreign organization in Ethiopia. USAID works in more than 100 countries on everything from agriculture to governance. "The United States Agency for International Development (USAID) is the United States Government agency which is primarily responsible for administering civilian foreign aid."58

Another origin country of the Relief and Development Aid Organizations is Germany. Germany has the following Governmental and Non-Governmental Organization which are involved in humanitarian and development projects in Ethiopia.

1) The German Federal Ministry for Economic Cooperation and Development (BMZ)

2) The German Federal Ministry of Food and Agriculture (BMEL)

3) The German Federal Environment Ministry (BMU)

4) German Technical Cooperation (GTZ) but since 2011 renamed into German International Cooperation (GIZ)

5) German Development Service (DED) since 2011 under GIZ

6) International Further Training/Education gGmbH (InWent) since 2011 under GIZ

7) Kredit für Wiederaufbau (KfW) (Development Bank: Credit for Rebuilding)

8) German Academic Exchange Service (DAAD)

9) Senior Experts Service (SES)

10) Deutsche Welthungerhilfe (“German Agro Action”)

${ }^{58}$ Source: USAID website. 
11) Menschen für Menschen/(“People for People”/from Karl-Heinz Böhm)

12) Brot für die Welt (protestant/evangelical church)

13) MISEREOR (catholic church)

14) German Foundation for World Population Deutsche Stiftung Weltbevölkerung (DSW)

15) Friedrich-Ebert-Stiftung (Foundation)

16) Heinrich-Böll-Stiftung (until 2012)

17) CARE INTERNATIONAL

18) OXFAM International (OXFAM Germany)

However, the German Technical Cooperation (GTZ/GIZ), the German Development Service (DED/GIZ) and International Further Training/Education gGmbH (InWent/GIZ) are working in Ethiopia on behalf of the German Federal Ministry for Economic Cooperation and Development (BMZ).

Moreover, there are Relief and Development Aid Organizations from Canada, France, Italy, Sweden, The Netherlands, Belgium, Japan, United Kingdom, Ireland, Norway, etc. who are engaged in Ethiopia.

But the question is, since when have been the Relief and Development Aid Organizations working in Ethiopia and in which sector exactly are they involved?

According to the source of USAID, USAID has provided assistance to Ethiopia since its inception in 1961. Therefore, since 1961 USAID provides assistance in: Agriculture and Food Security: "Through Feed the Future, USAID enhances food security, increases agricultural productivity, and promotes resilience, especially among vulnerable populations."

USAID has documented in its annual report under the title "EVOLUTION OF USAID OBJECTIVES IN ETHIOPIA" about its "DEVELOPMENT PRIORITIES IN ETHIOPIA IN THE 1960s 1962-1969 and "Strategic Objectives" in Ethiopia from 1962 up to 2013/2014. ${ }^{59}$

Hereto said USAID concerning Ethiopia's problem under the title: "Agriculture and Food Security" as follows:

"Agriculture and Food Security: Ethiopia's economy is dependent on agriculture, and the country's rapidly growing population underscores the need for sustainable and high-quality access to food." 60

USAID said further: "Through Feed the Future, USAID enhances food security, increases agricultural productivity, and promotes resilience, especially among vulnerable populations. Ethiopia's economy is dependent on agriculture, which contributes 43 percent of the GDP and 90 percent of exports. However, just five percent of land is irrigated, and crop yields from small farms are below regional averages. Market linkages are weak, and the use of improved seeds, fertilizers and pesticides remains limited." ${ }^{61}$

But the question is, why couldn't be the following big rivers and lakes in

${ }^{59}$ Source: CBJ FY 1962: http://pdf.usaid.gov/pdf_docs/PNAAX630.pdf

${ }^{60}$ Source: website: USAID: October 25, 2011; September 12, 2012; December 18, 2012; February 7, 2013; January 31, 2014, Last updated: December 22, 2014. 
Ethiopia used for irrigation:

\section{The big rivers:}

Blue Nile, Awasch, Tekeze, Akobo, Omo Wenz, Genale Wenz, Wabi-Shebele,

The big lakes are: Lake of Tana (the source of Blue Nile), lake of Abaya, lake of Ziway, lake of Fincha, Chew Bahir, lake of Abhe, lake of Turkana, lake of Chamo, lake of Hawassa.

Due to its large number of rivers and lakes, Ethiopia is referred as "water tower" or the mother of water". Therefore, what are the reasons for the low percentage of land irrigation in Ethiopia, what USAID has reported above? USAID said further under the title: "EVOLUTION OF USAID OBJECTIVES IN ETHIOPIA" in 1995 about its "Sustainable Development Goals and Mission Strategic Objectives" for example "Stabilizing Population Growth [and] Reduce Fertility" among others. Because the opinion of USAID is that "Ethiopia faces an array of development challenges, including rapid population growth, food insecurity, limited space for private sector development, and concerns about democratic governance following the 2010 elections." However, USAID repeats its opinion about the impact of population growth in Ethiopia every year as the following statement shows: "Ethiopia faces an array of development challenges, including rapid population growth, food insecurity, limited space for private sector development, and concerns about democratic governance following the 2010 elections." 62

But according to USAID the major areas of its assistance in Ethiopia are as follows: “Feed the Future: USAID's Feed the Future Strategy in Ethiopia focuses on three core components:

- agricultural growth-enabled food security

- linking the vulnerable to markets, and

- fostering a regulatory environment and private sector conducive to economic growth and targeting 149 Woredas (Zones) containing a combined population of 20 million people

- Food Assistance

- Economic Growth and Trade, Private Sector and New Alliance for Food Security and Nutrition

\section{Grant Opportunities}

- Powering Agriculture: An Energy Grand Challenge for Development Second Global Innovation Call

- Livestock Production: Livestock and Dairy: USAID launches New Livestock Market Development Project (November 17, 2012 and (April 25, 2013)

- Empowering Women in Ethiopia: Empowering Women through Agricultural Development in Ethiopia”

\footnotetext{
${ }^{61}$ Source: website: USAID: October 25, 2011; September 12, 2012; December 18, 2012; February 7, 2013; January 31, 2014, Last updated: December 22, 2014.

${ }^{62}$ Sources: CBJ FY 1995, pp. 71-71: pdf.usaid.gov/pdf_docs/PNABQ736.pdf; CBJ FY 2012, pp. 60-68: http://pdf.usaid.gov/pdf_docs/pcaac378.pdf; CBJ FY 2013, pp. 58-66:

http://pdf.usaid.gov/pdf_docs/pcaac382.pdf; "Evolution of USAID Development Priorities in Ethiopia”-US Agency for... https://www.usaid.gov/.
} 
Moreover, USAID is involved in the following sectors in Ethiopia, according to its statements:

\section{- Education}

USAID works with the Ministry of Education and donors to improve student learning outcomes, particularly in early grade reading. USAID's education program helps millions of students advance in their education while building the capacity of teachers and key host-government institutions."

\section{- Health, Industry, Textiles, Mining, Natural Resources, Environment}

"Protecting the environment preserves biodiversity and revitalizes pastoral lands Nena Terrell/USAID. [...] By incorporating environmental issues into its efforts within Ethiopia, USAID strives to develop initiatives that make improvements across sectors and promote sustainable development. USAID programs also support biodiversity conservation in some of the remaining natural forests and the revitalization of rangeland productivity in pastoral areas. [...] However, the bulk of that assistance was concentrated on the agricultural sector. Toward the end of the decade, USAID objectives in Ethiopia expanded to include building human capacity."

Economic Growth and Trade: New Alliance and Private Sector

"State dominance over the economy severely limits access to credit, private land ownership, and agricultural inputs. USAID works to strengthen small and medium-sized enterprises and smallholder farms, providing access to credit and technical support."

USAID said further that U.S. assistance improves health, food security, and education in Ethiopia. ${ }^{63}$

Another question is that what does the assistance of USAID to Ethiopia cost?

According to USAID the cost of supplying USAID's assistance to Ethiopia is the fourth top among the 20 Countries with the Largest Budgets for U.S. Economic Assistance in Fiscal Year 2012, i.e.

1) Afghanistan 2.24 Billions of Dollars

2) Pakistan 0.97 Billions of Dollars

3) Jordan 0.48 Billions of Dollars

4) Ethiopia 0.45 Billions of dollars

However, "USAID and U.S. foreign economic assistance in general have been the subject of debates, controversies, and criticisms continuously since the 1950s."

German Governmental and Non-Governmental Organizations in Ethiopia

The German Federal Foreign Office (Auswärtiges Amt) describes Ethiopia under the title: Short Characterization" ("Kurzcharakterisierung”) as follows:

1) Ethiopia is one of the poorest countries in the world (LLDC) with annual gross national income of about 370 US-Dollar per head (2012, Atlas-Methode)

${ }^{63}$ Source: USAID-website: October 25, 2011; September 12, 2012; December 18, 2012; February 7, 2013; January 31, 2014, Last updated: December 22, 2014.

${ }^{64}$ Source: Internet. 
and it has about 87 million citizens. ${ }^{65}$

2) The area of Ethiopia is 1.1 million square kilometer (to compare: Germany 357.000 square kilometer), [i.e. more than three times bigger than Germany].

3) Population: 99.3 million (in accordance with World Bank, 2015), growth rate 2.47 percent (in accordance with World Bank, 2015) (according to census 2007).

4) Population density: 83 citizens/square kilometer (Germany: 226).

5) Climate: Three [four] zones: Up to 1.000 meter moisture or hot and dry; 1.000 - 2.5000 meter moderate, average temperature: 20-25 degree Celsius; above 2.500 meter cool [above 2.500 meter cold and ground frost] (in Addis [Ababa] annual average temperature 16 degree Celsius); rainy season in high land June-September as well as February-April. ${ }^{66}$

The German International Cooperation (GIZ) said that the rural population in Ethiopia is affected by increasingly food insecurity since several decades. According to GIZ, this is the result of rapid population growth, the increasing deforestation, as well as insufficient method of production in the agricultural sector. At the same time the private sector still weak. The country [Ethiopia] had in 2011 roughly 85 million citizens and it is three times bigger than Germany. ${ }^{67}$

As already noted above the German Federal Foreign Office (Auswärtiges Amt) and the GIZ argue the same as USAID that rapid population growth in Ethiopia is the obstacle for economic growth and the cause for steady soil erosion. The German Federal Foreign Office said further that also lack of resources is a cause of the structural problems in Ethiopia. Therefore, such problems remain unresolved despite huge efforts. ${ }^{68}$

The fact that there is no evidence for the arguments of USAID, German Federal Foreign Office and GIZ that "rapid population growth" in Ethiopia is the hindrance for economic growth and the cause of soil erosion, the researcher of this paper will discuss and find out the real causes of these and other problems in Ethiopia at the end of this paper.

But the question is, where did the population sizes of Ethiopia come from, because there is no infrastructure or institution like Municipality or districts who can register:

- birth rate

- death rate

- internal migration and

- emigration (external)

The Ethiopian government had announced on $4^{\text {th }}$ August 2016 to launch nationwide vital events registration system in Ethiopia for the first time in the his-

\footnotetext{
${ }^{65}$ Source: German Federal Foreign Office/Äthiopien: Deutsches Auswärtige Amt: Wirtschaft Äthiopiens (report as at March 2013)

${ }^{66}$ Source: Deutsches Auswärtige Amt (2016): Äthiopien: Stand: October 2016 website:

https://www.auswaertiges-amt.de/

${ }^{67}$ Source: GIZ: Äthiopien-https://www.giz.de/de/weltweit/

${ }^{68}$ German Federal Foreign Office/Deutsches Auswärtige Amt (2013): Wirtschaft Äthiopiens, Stand: März 2013 and GIZ: Äthiopien-https://www.giz.de/de/weltweit/
} 
tory of the country. ${ }^{69}$

Also such contradictions will be discussed in this research paper.

Another question is, since when have been the German Relief and Development Aid Organizations working in Ethiopia and in which sector are they engaged?

According to the German Federal Foreign Office (Auswärtiges Amt) the bilateral development cooperation between Germany and Ethiopia had begun 50 years ago. According to the German Federal Foreign Office Ethiopia has received a total of more than EUR 1 billion under Technical and Financial Cooperation ever since. [...] "Ethiopia is a priority country of German development cooperation." ${ }^{p 0}$

According to its source the German development cooperation focuses on the following three priority areas:

- Education (vocational training and higher education)

- Food security and agriculture

- conservation and sustainable use of natural resources; biodiversity

The German Federal Foreign Office said further that "Germany made new commitments totaling EUR 133.8 million under government development cooperation with Ethiopia up to 2017 (including a special commitment in November 2014; in addition, some EUR 6 million was rededicated). [...] Besides the [German] Federal Ministry for Economic Cooperation and Development (BMZ), the [German] Federal Ministry of Food and Agriculture (BMEL) and the [German] Federal Environment Ministry (BMU) are also engaged in development cooperation with Ethiopia."

Moreover, the Deutsche Welthungerhilfe ("German Agro Action") is engaged in Ethiopia since 40 years. According to the source of the Deutsche Welthungerhilfe ("German Agro Action") it is one of the biggest political and confessional independent Non-Governmental Organization in Germany. It was founded in 1962 under the umbrella of the UN-Food and Agricultural Organization (FAO). The Deutsche Welthungerhilfe is under the umbrrella of the German Federal president. Currently it is under the umbrella of president Joachim Gauck.)

As already noted above, the Deutsche Welthungerhilfe ("German Agro Action") is active in Ethiopia since 40 years. According to its statements this organization is "fighting to eradicate poverty. Our aim is that our will be unnecessary. We provide assistance from one hand, i.e. from the quickly humanitarian aid up to long term investment of development cooperation projects."

But Deutsche Welthungerhilfe ("German Agro Action") said that many circumstances are changed and some are remained the same. Anyway Deutsche

\footnotetext{
${ }^{69}$ Sources: Ethiopian Broadcasting Corporation/ETV on $4^{\text {th }}$ August 2016 and "The Ethiopian Herald" newspaper on $5^{\text {th }}$ August 2016, No. 282, page 1 and 2.

${ }^{70}$ German Federal Foreign Office/Äthiopien: Deutsches Auswärtige Amt: Wirtschaft Äthiopiens (report as at March 2013.

${ }^{71}$ Source: Website of German Federal Foreign Office, Last updated in October 2016 see also website of the Federal Ministry for Economic Cooperation and Development, and website of the German Embassy in Ethiopia.
} 
Welthungerhilfe (“German Agro Action") appeals permanent for funds and its slogan says: "30 Euro is enough for one small garden in a town in Ethiopia to plant nourishing vegetable. Donate now. Every donation helps!”72

In addition to the above listed organizations, there is another Non-Governmental Organization which is an umbrella for many NGOs in Ethiopia, i.e. Consortium of Christian Relief and Development Association (CCRDA).

According to its source, CCRDA is an association of non-governmental and civil society organizations that lobby for poverty alleviation and policy advocacy.

"CCRDA was "founded in 1973 in response to famine in Ethiopia, [...] As of February 2010, 334 member agencies are operating in Ethiopia, 73 percent of which are indigenous." ${ }^{\text {73 }}$

CCRDA said further about its activities in Ethiopia include urban and rural development with an emphasis on food security, health education, HIV/AIDS awareness, water and sanitation, good governance, environmental protection, and civic education.

According to the Acting Deputy Mission Director Elise Jensen of USAID, there is cooperation between CCRDA and USAID concerning their mission in Ethiopia. Jensen said on November 28, 2014 on the Annual Membership Assembly of CCRDA: "Thank you for inviting USAID to be with you today. It's important because we already share many partnerships between and among USAID and CCRDA members. It's also important because USAID seeks to expand even more our cooperation and support to Ethiopian civil society and nongovernmental organizations engaged in many different aspects of development around Ethiopia. USAID and CCRDA share a common mission in Ethiopia." $^{74}$

But the question is, how do the Ethiopian Government and the foreign Governmental and Non-governmental Organizations explain the contradictions, i.e. the economic, social, political and ecological problems especially the food insecurity in Ethiopia are not still solved despite the double-digit economic growth in the country on one hand and the activities of thousands of Governmental and Non-Governmental Organizations in Ethiopia on the other hand?

Many foreign Non-Governmental Organizations and international mass media have reported at the beginning of 2016 with dramatic headlines on food crisis in Ethiopia as follows:

For example: Oxfam International has reported under the title "Ethiopia food crisis" as follows: "A devastating drought in Ethiopia is causing the worst food crisis that the country has faced in 30 years. We must act now to protect millions from hunger and disease. With your help we can reach men, women and children in desperate need with life-saving clean water and food.

[...] The number of people in need is rising rapidly with men, women and

\footnotetext{
${ }^{72}$ Source: https://www.welthungerhilfe.de/.../40-jahre-welthungerhilfe-in-aethiopien./

${ }^{73}$ Source: https://berkleycenter.georgetown.edu/.../consortium-of-christian-relief-and-developm

${ }^{74}$ Source: https://www.usaid.gov/.../annual-membership-assembly-consortium-christian-relief-an Nov 28, 2014-USAID and CCRDA share a common mission in Ethiopia.
} 
children in urgent need of food and clean, safe water. The Ethiopian government estimates that more than 9 million people will need humanitarian assistance in 2016."75

Another headline from BBC World News was as follows: "Hunger crisis in Ethiopia worsens amid drought. UN Secretary-General Ban Ki-moon has visited a drought-hit region of Ethiopia to help raise awareness of the worsening hunger crisis. More than 10 million people are short of food amid one of the worst droughts for decades."76

However, other mass media have reported that 18 million people need food aid in Ethiopia. ${ }^{77}$

Also the Deutsche Welthungerhilfe ("German Agro Action") has reported about the food crisis in Ethiopia in 2016 under the title: "Drought in Ethiopia" as follows: "Hunger, water shortage and poor harvests: results of El Nino. 10 million people in Ethiopia are threatened from extreme hunger. We support the people to overcome the crisis. Your donation helps." ${ }^{\text {"78 }}$

As already noted above, many NGOs and international media have reported in 2016 about the food crisis in Ethiopia in an alarming scenario. For example Oxfam International said under the title: "Ethiopia food crisis" as follows: "A devastating drought in Ethiopia is causing the worst food crisis that the country has faced in 30 years. We must act now to protect millions from hunger and disease."

Also the UN-World Food Programme (WFP) has reported on 3 February 2016 under the title: "Drought in Ethiopia: 10.2 Million People In Need" as follows: "Ethiopia is in the grip of its worst drought in recent history. More than ten million people are in need of assistance according to the Government and humanitarian agencies. On Sunday 31 January, the UN World Food Programme (WFP) Executive Director Ertharin Cousin and UN Secretary-General Ban $\mathrm{Ki}$-moon visited Ethiopia to see first-hand the consequences of the drought in one of the worst affected areas."

Therefore, clarification is expected from the Ethiopian Government and the local as well as the foreign Governmental and Non-governmental Organizations for the contradictory facts in Ethiopia.

This means that despite huge natural and human resources of the country for example fertile land, four different climate regions, the double-digit economic growth, thousands of foreign and local organizations engaged in Ethiopia on one hand and the economic, social and environmental problems of the country, especially the food crisis repeatedly since many decades on the other hand.

However, according to many organizations and the Ethiopian government, the food crisis in 2016 was averted by the Ethiopian government from its own resources. Oxfam International said: "Although the government of Ethiopia is

\footnotetext{
${ }^{75}$ Source: https://www.oxfam.org/en/emergencies/ethiopia-food-crisis

${ }^{76}$ Source: BBC World News (2016)

${ }^{77}$ Source: www.n-tv.de, June 11, 2016

${ }^{78}$ Source: https://www.welthungerhilfe.de/
} 
taking a strong lead in responding to this drought, and almost 8 million people will receive help from the government-led safety net, more is urgently needed."

James Jeffrey has quoted John Graham, Save the Children's Ethiopia country director about the response of the Ethiopian government to the drought in 2016 as follows: "The present situation here keeps me awake at night," says John Graham, Save the Children's Ethiopia country director.

"The government has shouldered much of the financial burden so far, but if they don't get more immediate help from foreign donors they may be forced to redirect funding from other vital areas, including education and maternal and child health programmes, in order to buy life-saving food aid."79

Also Edmund Blair has written that: "Ethiopia urged international donors on Sunday to offer aid promptly for relief operations to support 10.2 million people critically short of food, and said it was committed to allocating as much of its own funds as necessary. [...] The government says donors have covered about 30 percent so far." 80

Moreover, Ms. Ahunna Eziankonwa-Onuchie, United Nations Resident and Humanitarian Coordinator for Ethiopia said at the World Humanitarian Summit (WHS) in Istanbul on 23 May 2016 about the response of the Ethiopian government to the food crisis in 2016 as follows: "The Ethiopian response model is evidence that resilient development saves lives and protects development gains". ${ }^{81}$

Similarly said Mr. Demeke Mekonnen Ethiopia's Deputy Prime Minister at the World Humanitarian Summit (WHS) in Istanbul on 23 May 2016 about the response of the Ethiopian government to the food crisis in 2016 that the Ethiopian government had supplied food, water, drug to drought-affected people. "Deputy Prime Minister Demeke Mekonnen said the government is doing its level best to withstand the drought caused by the current El Nino weather phenomena. He said further: "In addition to emergency food assistance, the government is distributing nutritious food for children and supplying animal feed to mitigate the effect of the drought on animals, Demeke told FBC [Fana Broadcasting Corporate] on Tuesday" and World Humanitarian Summit (WHS) in Istanbul on 23 May 2016).

According to the Deputy Prime Minister Demeke Mekonnen: “The humanitarian response during the year 2015 has faced serious constrains due to competing global crisis around the world. This made Ethiopia the least priority country for humanitarian support. Hence, the federal government so far has spent more than 300 million USD from its own budget. Regional governments have also contributed towards the response efforts. Above all, what is impressive is the reaction by the private sector and local communities: in different parts of the country businesses and public servants are making in kind and financial contri-

\footnotetext{
${ }^{79}$ Jeffery (2016): “Ethiopia’s drought response: success or anguish?”, in: African Businesses.

${ }^{80}$ Blair (2016); Editing by Andrew Bolton.

${ }^{81}$ Source: Ethiopia showcases best practices in drought response at WHS side event REPORT, from UN Office for the Coordination of Humanitarian Affairs, published on 23 may 2016.
} 
butions. In recent weeks, the international community has also stepped up with generous contribution of around 570 million US dollar. Thanks to our peoples' resilience, our country's double digit economic growth and the international community's support, so far we have managed to contain the situation." 82

However, some organizations like the UN-World Food Programme and the USAID have pledged, according to the "The Ethiopian Herald" as follows: "According to the UN, the drought so far affected over 10.2 million people across the country [Ethiopia]. The government [Ethiopian] has made the greatest financial support allocating 321 million USD so far. [...] World Food Programme and USAID representatives also pledged further financial assistance to help the Ethiopian government to contain the crisis. USAID announced a donation of additional 97 million USD in humanitarian Aid." ${ }^{83}$

But the question is, why the NGOs have reported in an alarming scenarios about the drought in Ethiopia in 2016 although they have pledged insignificant to avert the impeding food crisis as the above noted examples show, i.e. they collect many for 10 - 15 million people in Ethiopia alone but they give too little money to the people. According to Jan-Christoph Kitzler, most of the NGOs have made vague voluntary assistance pledges instead of real donations to avoid the food crisis in Ethiopia in 2016, although the situation was life-threatening for 15 million people. ${ }^{84}$

The question is, what could be happened if the Ethiopian government could not respond adequately to this drought in 2016 ?

The question is, what is the role of the "Foreign Development Aid Policy" and the Governmental and Non-Governmental Organizations in Sustainable Development in Africa, the case of Ethiopia if the African countries like Ethiopia, Nigeria, Democratic Republic of Congo (DRC), etc. face food shortage and depend on foreign food aid?

In other words, what is their duty in these countries, if they do not solve at least the food insecurity?

Criticisms against the publicity and development aid policy of many NGOs

There are criticisms not only against the practices of the "Foreign Development Aid Policy" in the Third World Countries for instance in the African countries but also on the publicity and the development aid policy of many NGOs. Many critics describe the vested interests of many NGOs as "pity" or "aid industry". One critic says: "Food aid of aid industry makes rich farmers beggar".

According to the critics against the publicity and development aid policy of many NGOs that they create emotions or pity in the public of the donor countries by showing very poor people in the Third World Countries in order to get ${ }^{82}$ Source: EBC [Ethiopian Broadcasting Corporation], 11 November 2015 Addis Ababa and Istanbul 23 May 2016.

${ }^{83}$ Source: "Ethiopia: UN Appeals for More Humanitarian Aid to Contain Drought Impacts", by Desta Gebrehiwot, 2 FEBRUARY 2016 Copyright (C) 2016 The Ethiopian Herald. All rights reserved Distributed by AllAfrica Global Media https://allafrica.com

${ }^{84}$ Kitzler, J-C. (03.02.2016) ARD-Studio Rom. 
donation but unfortunately many NGOs use the donation for their own interest, i.e. for their own carrier and business.

Henri Astier has reported about behaviors of many NGOs in the BBC under the title "Can aid do more harm than good?" as follows: "When Niger's president last year accused aid agencies of exaggerating his country's food crisis for their own gain, Western media reacted with shock. [...] "Sometimes aid agencies overplay figures in order to sustain themselves. What Niger experienced in 2005 was not a sudden catastrophe, but chronic malnutrition that makes people vulnerable to rises in food prices. Glib talk of famine backed by pictures of starving children may help NGOs raise funds, but it does nothing to address these basic problems, says Mr [William] Easterly." "I think NGOs and rich country media do have an incentive to paint too simplistic and bleak a picture, as was the case in Niger's food crisis," "Professor William Easterly of New York University told the BBC News website". ${ }^{5}$

"Tony Vaux, a former official with Oxfam, agrees. Once an emergency is identified, he says, the NGOs' public relations machine takes over and 'there is a terrible temptation to look around for the very worst stories'. 'The payoff is disappointingly low, he says. Getting the relief effort up and running takes time, and when the food arrives it is often too late-or the crisis has eased on its own, as appears to be the case in Niger. Emergency aid may relieve the situation-but the same amount spent before children starved in front of the cameras would have saved many more lives. Such poor returns were illustrated by the 2002 southern Africa 'crisis'. Camera crews went in to film starving babies and aid flooded in. According to UN agencies and many commentators, this played a crucial in averting disaster. [...] Take the case of Zambia, which at the time banned aid because it worried about genetically-modified US maize. [...] But at the very least, it seems clear that Zambia did not need a massive food influx to avert catastrophe. 'NGOs flatter themselves into thinking that they save lives,"' says former Zambian Agriculture Minister Guy Scott, who finds it "arrogant of the West to think that without whites, without pop stars, Africans would all be dead'. [...] The West tends not only to overstate the effectiveness of aid, but also to underestimate its harmful effects." 86

Also the Ethiopian government had accused Non-Governmental Organizations like for example the United Nations International Children's Emergency Fund (UNCEF) that they exaggerate the number of people who need foreign food aid in Ethiopia. According to the Ethiopian government, the government had requested the international donors for food aid for 6 million people, the NGOs like UNICEF had appealed donation rather for 13 Million people in Ethiopia. However, the Ethiopian government said, the NGOs were not willing to give the donation even to the 6 million people who needed help, but rather for 4 million people.

Not only governments criticize the behaviors of many relief aid agencies but

${ }^{85}$ Astier (2006): in: BBC News website.

${ }^{86}$ Ibid. 
also many more experts like for example Linda Polman, the former Ethiopian Prime Minister Meles Zenwai, James Shikwati, Erich Wiedermann describe such characters of many NGOs as "aid industry" or "pity industry".

James Shikwati criticizes the NGOs that they are self-seeking, because they collect money for themselves and they are engaged in pure business. He said further that instead of helping poor people the NGOs propagate negative images or impressions against Africa and create fear and tension that tourists and investors stay away. ${ }^{87}$

According to Volker Seitz European mass media talks about devaluating Africa as a "hunger continent".

Linda Polman describes "aid as business" for the NGOs. Therefore, Polman recommends the population who donate to be critically examine the NGOs whether the NGOs fulfill their promises which they make. ${ }^{88}$

Erich Wiedermann describes development aid policy under the title: "Helping the Hungry: Addicted to Aid in Ethiopia" how the famine relief keeps Ethiopia in poverty. ${ }^{89}$

Also the German Magazine "Stern" deals with the topic "aid industry" under the title "aid is a business". 90

Criticisms against activities of foreign Governmental and Non-Governmental Organizations are not isolated case of a government in the Third World Countries or some experts but they are common in many countries in the world as the following examples show: "The government [of Egypt] has accused the aid workers, who have been banned from traveling, of setting up branches of international organisations in Egypt without a license from the government and of receiving illegal foreign funding. A total of 43 people are facing trial. Five Serbs, two Germans and three non-Egyptian Arab nationals are also among those referred to trial, AP reported. [...] Sixteen Americans-including transportation secretary's son Sam LaHood are among 43 staff guilty of receiving foreign funding. [...] Security forces raided the offices of 17 local and international NGOs in December as part of a probe into illegal funding." ${ }^{\text {"1 }}$

Also "The Guardian" has reported the same as above about the activities of many NGOs in Egypt as follows: "A Cairo criminal court has convicted 43 NGO workers, including at least 16 Americans, of operating without a licence and receiving foreign funding. The case had sparked international outrage, souring relations between Egypt and the US, and inflaming domestic fears over the potential for foreign funding to influence internal political affairs. Twenty-seven of the defendants, all of whom were tried in absentia, received prison sentences of five years. Eleven of those who attended the trial received one-year suspended sentences, and five others received two years." ${ }^{92}$

\footnotetext{
${ }^{87}$ Shikwati (2007) and in Internet: "Development Aid in the criticism", in: "n-tv" POLITIK".

${ }^{88}$ Polman (2010): “Die Mitleidsindustrie”, Campus Frankfurt am Main; New York.

${ }^{89}$ Wiedemann (2005): in: "Spiegel Online International".

${ }^{90}$ Wüllenweber (2011): "Die Hilfsindustrie", in: "Stern-Artikel”

${ }^{91}$ Haddadi, A. (02.06.2012): "International Business Times".
} 
However, the US and German governments have officially protested against the action of the government of Egypt no matter what the NGOs have done in Egypt.

Despite the threat of the US government to cancel aid, Egypt's prime minister will not obviate such blackmail. According to BBC News: "Egypt PM dismisses US aid threat over activists' trial. Egypt has said it will not be persuaded by the potential loss of US aid to end an ongoing investigation into foreign-funded non-governmental organisations. Prime Minister Kamal Ganzouri said his government would" "apply the law" in the case of the NGOs and "not back down".

Therefore, the question is, do foreign organizations have "unlimited right" in other countries?

What would happen, if foreign organizations engage in politics and fund raising in the USA or Germany without license? Anyway the government of Egypt describes the activities of the NGOs and the reaction of the governments of the USA, Germany etc. as "foreign conspiracy" to destablize and weaken Egypt. ${ }^{94}$

Moreover, many Governmental and Non-Governmental Organizations and the international media have reported that, the Ethiopian Government has suspended 42 NGOs because of the following reasons: " 42 NGOs suspended for being involved in activities 'out of their mandate'. [...] Ethiopian Prime Minister Meles Zenawi speaks to the media at his office in Addis Ababa, April 13, 2009. Ethiopian authorities have suspended the operations of 42 non-governmental organisations allegedly involved in activities that are 'out of their mandate' in the Southern region of the country. The Ethiopian government moved to revoke the licence of the NGOs following accusation of their alleged involvement in reporting human right abuses in the rural areas. Ethiopian government publicly accused some NGOs of supplying "inaccurate" information to the United States' State Department, which was published in March 2009." ${ }^{\prime 95}$

As already noted above, the Ethiopian Government has accused some NGOs that they were involved in activities "out of their mandate". But in order to understand and judge the accusation of the Government we should have the information about the mandate and license of the NGOs.

What is their mandate and what are the binding agreements which are signed between the NGOs and the Ethiopian Government about the activities of the NGOs in Ethiopia?

The German Embassy in Ethiopia said that in addition to the bilateral cooperation between the German and Ethiopian governments, the German government supports projects of NGOs, i.e. from church institutions and political foundations with main activities in rural development, health, drink pure water supply, and education and also "development partnership" with the industry in Ethi-

\footnotetext{
92“"Egypt convicts US NGO workers | World news | The Guardian”, Louisa Loveluc, 04.06.2013.

${ }^{93}$ BBC News, Middle East, 08.02.2012.

${ }^{94}$ Source: ARD-Tagesschau [German Broadcaster news] (2012)

${ }^{95}$ Daily Nation (2009): REUTERS
} 
opia.

However, the German embassy said that the NGOs are responsible for the implement of the projects. Although the German Government supports the NGOs they are independent. According to the German Embassy, the activities of the German NGOs in Ethiopia must be governed by the Ethiopian law makers and must be registered by the appropriate authority. The German Embassy said further that the new law which the Ethiopian Government passed in 2009 is restrictive and many NGOs have therefore difficulties to fulfill the expected legal requirements. ${ }^{96}$

But the question is, what does this new Ethiopian law of 2009 mean?

According to a report of "International Journal of Not-for-Profit Law" the Ethiopia's new civil society law or the Code of Conduct of Non-Governmental Organizations means as follows: At the result of the 1973-74 and 1984-1985 famines in Ethiopia many non-governmental organizations (NGOs) emerged with a focus on relief and humanitarian activities but since 1991, i.e. the present Government came to power, the number of NGOs increase very rapidly. The fact that many more NGOs are emerging in Ethiopia, the Ethiopian Government had in 1995 provided Guidelines for NGOs' operations to classify groups and provided guidance on the priority areas for NGOs programming. The areas designated were broad and included agriculture, environment, education, health, women's empowerment, infrastructure, and the like. ${ }^{97}$

Also Jeffrey Clark said that Guidelines for NGO Operations was put into place already by the King of Haile Selassie in 1960. [...] "That law provided the basis for the regulation procedures detailed by the Ministry of Internal Affairs in 1966 with the issuance of" 'Regulations Issued Pursuant to the Control of Associations Provision of the Civil Code of 1960.' 'The government's 1995 Guidelines for NGO Operations updates those procedures, outlines major classifications for the sector, and defines areas for programmatic activities. Registration of NGOs is under the authority of the national Ministry of Justice. Before 1995, this responsibility rested with the Disaster Prevention and Preparedness Commission (DPPC). Once registered, NGOs' operations are then under the supervision of the DPPC and the Bureaus for Disaster Prevention and Preparedness (BDPP) at the regional level." ${ }^{\prime 98}$

In 2009 the Ethiopian Government adopted the Proclamation (No. 621/2009) to Provide for the Registration and Regulation of Charities and Societies (CSP), Ethiopia's first comprehensive law governing the registration and regulation of NGOs.

According to the report of Owen Barder, this Proclamation limits the activities of foreign-funded organizations. This law prevents organizations that receive more than $10 \%$ of their funding from abroad from involvement out of their

\footnotetext{
${ }^{96}$ Source: Deutsche Botschaft Addis Abeba-NGOs in Äthiopien (2018): https://addis-abeba.diplo.de/. ${ }^{97}$ See: Global Development Research Center (1999).

${ }^{98}$ Clark (2000): “Civil Society, NGOs, and Development in Ethiopia A Snapshot View”: The World Bank Washington, D.C. First printing.
} 
mandate and [...] imposed stricter requirements for registration, like asking charities and civil society organizations to secure a letter of recommendation from the Ministry of Foreign Affairs.

However this law has been greeted with howls of protest by international organizations like for instance Heinrich-Böll-Foundation Barbara Unmüßig, President of the Heinrich-Böll-Foundation said: "A law passed in Ethiopia in 2009 prohibits all domestic NGOs receiving more than ten percent of their budget from abroad from engaging in any form of political activity." Barbara Unmüßig described this law as "exclusive work prohibition against critical minds". She said further: "Governments across all continents-irrespective of their political orientation and regime type-are taking drastic action against civil society actors: against non-governmental organisations, social and ecological activists, women's rights activists and human rights advocates. The space for actors who are critical of government policies, who call for democracy and human rights, who take an active stand against large-scale projects, and who protest against social injustice, land grabbing and environmental degradation is shrinking. [...] The freedom of press, speech and assembly had become dramatically restricted there over the past few years. The passing of laws on the role and functions of NGOs in 2009 as well as the implementation regulations of autumn 2011 reached new heights in political control and restrictions on the freedom to act. [...] Between March and September 2011, six Ethiopian journalists were arrested and charged with aiding terrorism; a further six journalists were tried in their absence. In December 2011, two Swedish journalists were sentenced to eleven years in prison, while two Ethiopian journalists were imprisoned to 14 years each in January 2012, and an exiled blogger was handed down a lifelong jail sentence.

In June 2012, renowned journalist Eskinder Nega along with 23 other people were found guilty of terrorist acts and also given long or life sentences. Critical journalists have, for years, felt that they had been pressurised and that their safety had been compromised. A number of newspapers were discontinued (e.g. Addis Neger in 2009, Awramba Times in 2011), and many critical journalists have fled the country before they would have faced charges. Argaw Ashine, the Chairman of the Ethiopian Environment Journalist Association and a long-standing partner of the Heinrich Böll Foundation, left the country in 2011 after his name had been cited in a report from the US embassy in Ethiopia published by WikiLeaks." ${ }^{99}$

However, there are other reports which are contrary to many criticisms of many NGOs like Heinrich-Boll-Foundation (Barbara Unmuessig). For instance, Owen Barder reports about the Proclamation of 2009 as follows: “I'm going to make myself very unpopular with lots of the ferenj [white people] here in Addis Ababa, many of whom make a good living working for NGOs with foreign 
funding and are up in arms about this. But I see where the Ethiopian Government is coming from, and I don't think the law is completely unreasonable. Now, don't get me wrong: I would not have brought in this law. I think 15 years imprisonment (that was in the draft bill) for breaking this law is draconian. I do not think that government officials should have the right to attend internal meetings of civil society organisations. But it is not unreasonable for the Ethiopian Government to say that foreign-funded organisations should not be able to use their funding to buy political influence and change in Ethiopia. Foreign donations to political parties are illegal in the UK-that is why there has been such a fuss about the allegations that George Osborne may have solicited donations from Russian oligarchs on a yacht. We are uncomfortable with the idea that very wealthy people should buy political power-that is why we have spending limits and caps on political donations-and in the UK we look rather pityingly at the United States, where funding by rich companies and individuals seems to dominate political life. Think what this must feel like in a very poor country, where even quite modestly wealthy organisations and individuals overseas have undreamt of wealth by comparison with Ethiopians, and try to use that disparity of wealth to buy change. So why shouldn't a very poor country be concerned to avoid having its politics shaped by foreign funding? There are about 3800 NGOs here in Addis, with a total budget of $\$ 1.5$ billion a year. (That is a lot of money in a country in which the annual government budget is about $\$ 4$ billion a year. The government health budget is less than $\$ 300$ million a year.) The money going to NGOs could make a huge difference if it were used to improve government services directly, rather than to fund a motley collection of advocacy organisations and fragmented small scale delivery organisations.

It is important to note that the new law does not forbid civil society organisations from being involved in advocacy for human rights. It forbids organisations from being involved in political advocacy if they get more than $10 \%$ of their funding from abroad. So while this law isn't one that I would have introduced myself, I see where the Government is coming from. It is not completely mad. The hysterical over-reaction from donors, often under political pressure from international NGOs at home, is out of all proportion." 100

\section{Also Yohannes A. asks: "What is behind the unremitting criticism of Ethiopia's law on NGOs?"101}

Therefore, the question is, shouldn't a government regulate or fixed Guidelines for NGO Operations in its own country? Concerning regulations of the law of associations said Barbara Unmuessig under the title "NGO legislation booming" as follows: "A veritable boom has broken out in so-called NGO laws governing relations between domestic and foreign non-governmental organisa-

\footnotetext{
${ }^{100}$ Barder (2009): “Aid effectiveness, Development, NGOs, Politics-Ethiopia's new civil society law-Owen abroad”, Addis Ababa, source: http://www.owen.org/blog/2086

${ }^{101}$ Yohnnes, A. (20.01.2014): "Rapid development of the non-governmental sector occurred in..... FOR ANY NGO THERE ARE BINDING AGREEMENTS SIGNED BETWEEN...”, jhoniabraha@gmail.com.
} 
tions (cash flow, registrations, reporting obligations, etc.). Laws of this nature are unquestionably legitimate. After all, we, too, are subject to the regulations of the law of association governing e. g. rules of non-profit status, taxation and the minimum standards for internal procedures, byelaws, elections, accountability, etc. However, it is vital that such regulations do not question the right of association but respect the independence of organisations." 102

However, contrary to Barbara Unmuessig's accusations Owen Barder said: "It is important to note that the new law [2009] does not forbid civil society organisations from being involved in advocacy for human rights. It forbids organisations from being involved in political advocacy if they get more than $10 \%$ of their funding from abroad." 103

The question is, also, how are the activities of NGOs or associations treated in Germany?

Aren't NGOs restricted or regulated in Germany like in the UK?

Do they have unlimited right to collect money in Germany and spend the money on unlimited purposes in and outside Germany?

The fact that the above quoted reports and accusations against the law which the Ethiopian government passed in 2009 that restricted NGOs fund raising activities and operations are contradictory, the researcher of this paper will discuss and evaluate in the discussion and conclusion parts of this paper.

This means, who is telling the facts and who is misleading the public?

Is there a political motivated campaign against the Ethiopian Government "behind the unremitting criticism of Ethiopia's law on NGOs?"

Whatever the facts of the cases in Egypt and in Ethiopia were, many foreign NGOs have demanded from their own governments to cancel development aid for Ethiopia.

But the question is, isn't such demand of the organizations blackmailing against aid recipient countries like Ethiopia or Egypt?

What would happen, if countries which are not aid recipient and expel foreign organizations which are accused to be engaged in politics and fund raising without license?

According to the reports of BBC News, "The Guardian", the German Broadcaster News ARD-Tagesschau and the newspaper "Süddeutsche.de" of 19.09.2012, Russia has expelled USAID due to intervention in internal affairs of Russia. "The Russian government gave the US until 1 October to close the mission, accusing it of meddling in politics.

USAID has worked in Russia for two decades, spending nearly $\$ 3$ bn ( $£ 1.8$ bn) on aid and democratic programmes. USAID has announced that it will close its offices in Russia following an order from the authorities there to cease operations." 104

Also the newspaper "The Guardian" has reported the same as above about the accusation against USAID by the Russian government under the title "USAID covertly influencing political processes, says Russia" follows: "Russian foreign

\footnotetext{
${ }^{102}$ Unmuessig (2012).

${ }^{103}$ Barder, ibid.

${ }^{104}$ Rosenberg (2012), BBC News, Moscow.
} 
ministry explains decision to expel the US agency for international development. Russia has accused the US of using its aid agency in Moscow to covertly influence the country's politics and elections, explaining its decision to expel the mission amid a wider crackdown on the opposition movement. The Russian government has given the US agency for international development (USAID) until 1 October to cease all operations in the country. The agency helps fund a number of pro-democracy and human rights groups that have provoked the Kremlin's wrath amid an unprecedented opposition movement against the Russian president, Vladimir Putin. In an uncharacteristically blunt statement, the Russian foreign ministry said that the decision to shut USAID was taken primarily because the agency's work "does not always correspond to [its] stated goals". "This means attempts to exert influence, via the distribution of grants, upon political processes, including elections of various levels and institutions of civil society," it said. ${ }^{105}$

Moreover the German Broadcaster News ARD-Tagesschau and the newspaper "Süddeutsche.de" of 19.09.2012 have also reported that Russia has accused the USAID due to intervention in internal affairs of Russia. However, the US Government as well as the German Government have protested against the action of the Russian government to expel the organizations. According to these reports, the US-Department has denied the intervention of its organizations like the USAID in internal affairs neither in Russia nor in other countries in the world. ${ }^{106}$

But the question is, why should the governments of Egypt and Ethiopia accuse the NGOs if such organizations are not involved in internal affairs, since these countries need aid from the NGOs?

Whatever the facts of these cases are, there are other reports which accuse the UN-Population Fund, the USAID and the World Bank etc. due to supporting sterilization by force 300.000 Peruvian women and 30.000 men in the 1990s. "A documentary about little known Peruvian social politics between 1995 and 2000, leading to the forced sterilization of 300,000 Peruvian women and 30,000 men."107

Moreover, the following authors and international media have reported about this sterilization programme in Peru in 1990s. "The programme, launched in 1996 by then-president Alberto Fujimori-who argued that a lower birth rate would drive down poverty-at first received much praise. But then more and more women complained about being sterilised without their consent. Most of them were poor, indigenous and spoke Quechua." 108

However, the question is, was this sterilization programme by force in Peru part of the birth control policy of the UN-Population Fund, the USAID, the 105“The Guardian" (2012).

${ }^{106}$ Source: “Spiegel Online" 20.09.2012.

${ }^{107}$ Sources: Le ventre des femmes (TV Movie: 2010)_IMDb, https://www.imdb.com/title/tt1734452/

${ }^{108}$ BBC World News (02.12.2015), Latin America \& Caribbean,, By Javier Lizarzaburu, Lima, “The Guardian": Peru's forcibly sterilised women find their voice|Global development ...

https://www.theguardian.com, World, Development, Peru, Jan 4, 2016-movies · tv \& radio, BBC World News, latin America \& Caribean, 02.12.2015, By Javier Lizarzaburu, Lima, "Frauen als Opfer des "Fortschritts": arte-tv Programm vom 04.06.2010 um 22:25 Uhr, Gaby Weber: "Der Inka" in den Köpfen”, Peru: 26.02.2012 15:00: “Gaby Weber: hat zuletzt für die Zeitgeschichte über nach Südamerika geflohene NS-Verbrecher während der fünfziger Jahre geschrieben”. 
World Bank etc. "to alleviate poverty"?

Anyway, according to BBC News and other media reports also the US government was accused of the following action. BBC News has reported under the title: "US medical tests in Guatemala "crime against humanity" as follows: "President Alvaro Colom I was upset and very angry US testing that infected hundreds of Guatemalans with gonorrhoea and syphilis more than 60 years ago was a "crime against humanity", Guatemalan President Alvaro Colom has said. President Barack Obama has apologised for the medical tests, in which mentally ill patients and prisoners were infected without their consent. Mr Obama told Mr Colom the 1940s-era experiments ran contrary to American values, Guatemala said. [...] President Obama also "underscored the United States' deep respect for the people of Guatemala and the importance of our bilateral relationship.

The study by Prof Reverby shows that US government medical researchers infected almost 700 people in Guatemala with two sexually transmitted diseases. The patients-prisoners and people suffering mental health problems-were unaware they were being experimented upon. The doctors used prostitutes with syphilis to infect them, or inoculation, as they tried to determine whether penicillin could prevent syphilis, not just cure it. The patients were then treated for the disease, but it is unclear whether everyone was cured. Prof Reverby has previously done research on the Tuskegee experiment, where the US authorities measured the progress of syphilis in African-American sharecroppers without telling them they had the disease or adequately treating it. The experiment ran from 1932 to 1972, with President Bill Clinton eventually apologising for it. The US has promised an investigation. [...] No offer of compensation has yet been made, but an investigation will be launched into the specifics of the study, which took place between 1946 and 1948. White House spokesman Robert Gibbs said on Friday the news was "shocking, it's tragic, it's reprehensible". In an interview with the BBC, Mr Colom said the test subjects were "victims of rights abuses". ${ }^{109}$ Also the "Catholic Answers Forums" has reported the same as above under the title: "That was a different medical atrocity" as follows: "Clinton apologized for what is known as the Tuskeegee Syphilis Experiment. This project started off as a noble attempt to provide syphilis care in the years before penicillin was founded to be an effective cure." 110

The answer to the question why this Research Paper is needed is the fact that:

1) The "Foreign Development Aid Policy" of the Western world didn't solve the economic, social and environmental problems of the Third World Countries for instance of Ethiopia although Ethiopia is resource rich country and despite more than 60 years "Foreign Development Aid" engagement of the Western world. In fact to the contrary: "The permanent receive of charity suffocates every

${ }^{109} \mathrm{BBC}$ NEWS (02.10.2010): US \& Canada, "US medical tests in Guatemala crime against humanity", http://www.bbc.co.uk/news/world-US-Canada-1145755

110"Catholic Answers Forums" (02.10.2010). 
initiative for self-help because "Foreign Development Aid" cements the dependency or immaturity of Africa. ${ }^{111}$

2) However, the Chines "Foreign Development Aid Policy" which is based on Help to Self-Help, Mutual Respect and Mutual Benefit contribute immense to the economic, social and environmental developments of the African countries like Ethiopia in a very short of time, i.e. within 10 years.

"The presence and conduct of China's foreign direct investment in Ethiopia since 2000 is fast becoming one of the fronts in reshaping Ethiopia's economic architecture. Given the fact that Ethiopia has been the major beneficiary of Chinese investment and cooperative development projects, the question that needs to be pondered is: can some of Ethiopia's spectacular growth rate be attributed to the Chinese investments? More specifically, have the Chinese cooperative investment footprints enabled the Ethiopian economy to master highly valued technology and generate productive employment or have the various Chinese investments destined Ethiopia's economy to be dependent on the Beijing Consensus model?" 112

The reasons why China has managed to help the African countries for instance Ethiopia in a short period of time contrary to the Western world are, as already discussed above, that the "Foreign Development Aid Policy" of the Western world is not based on Help to Self-Help, Mutual Respect and Mutual Benefit like the China's Foreign Development Aid Policy. Because China's Foreign Development Aid Policy was premised on equality between partners, mutual benefit, respect for sovereignty, respect for obligations and enhancing the self-reliance of Chinese aid recipients. ${ }^{113}$

As stated above, the China-Africa economic and trade cooperation experienced extensive, diverse and multi-level development, in contrast to the notion hyped by Western media that China is merely interested in African oil and resources. ${ }^{114}$ However, it is undeniable that China is a significant driver of African social and economic growth. "In recent years, African GDP growth is almost in lock step with that of China. According to statistics from World Bank, in 2009 Africa became the third most important contributor to global economic growth, only after China and India. Obviously, there were many factors driving Africa's rapid economic growth, but the China factor is increasingly gaining recognition. Emmanuel MBA ALLO, Ambassador of the Gabonese Republic, noted," "China sincerely cares about Africa, helps Africa, and truly hopes to see Africa grow and strengthen. China's development has provided more opportunities and potential for African countries' development". ${ }^{115}$

The increasing of China-Africa economic and trade cooperation, worries the 
Western world to "lose its vested interest in Africa, [which] has been maliciously attacking China-Africa relations, fabricating fallacies like "China is plundering African resources" or 'China is practising new colonialism in Africa' etc. Yet the facts from China-Africa economic and trade cooperation and voices from Africa have effectively vindicated China." 116

In contrast to the Western world, the "China-Africa economic and trade cooperation is a normal business relationship, having nothing to do with colonialism whatsoever. Taking international trade as an example, the Western developed countries often use their monopoly positions in international trade to sell their monopolized, over-priced industrial products to developing countries, and use their monopoly power to buy low-priced agricultural, mineral and other primary products, reaping huge monopoly profits through price scissors. If one looks at China's recent foreign trade (including China-Africa trade), one will see such a phenomenon: whatever China exports, its price will surely drop; whatever China imports, its price will surely rise. This shows China's trade balance is constantly being squeezed.

Therefore, the Western criticism in this regard on China trading its industrial products for African primary products is completely unjustified. In fact, they are the biggest beneficiaries from existing international economic order. Their real reason for attacking China is because China has touched upon their "exclusive" sphere (interest) in Africa." 117

The Western world accusation against China's Foreign Development Aid Policy in Africa which is based on Help to Self-Help, Mutual Respect and Mutual Benefit, equality between partners, respect for sovereignty, respect for obligations and enhancing the self-reliance of Chinese aid recipients, makes very clear that the Western world is worried, because the African countries which deliver huge mineral and agricultural resources unwilling to the Western world, will escape out of the "prisons" of the Western world and be free.

"Contrary to Western debt and assistance marked by various forms of economic and political overtones, China, using the South-South Cooperation, is in the process of bestowing a mix of loans with generous terms, debt forgiveness, infrastructure development, and other assistance to African nations so that they could be relieved from Western cultural, political, and economic hegemony. African governments have appreciated and responded enthusiastically to this new source of bottom-up, multiple, bilateral investment, trade, and aid because China has professed a willingness to ignore the political, conditional terms that characterize Western assistance." 118

The question is how China has achieved to help the African countries for example Ethiopia, i.e. what are the targets of China's investment in these coun-

${ }^{115}$ Guimei (2010): “China and Africa: Mutual Benefit and Win-Win: "Institute of Western Asian and African Studies, Chinese Academy of Social Sciences”, 2010-06-18 Guangming Daily.

${ }^{116}$ Ibid.

${ }^{117}$ Ibid.

${ }^{118}$ Desta (2009): “Chinese Investment in Ethiopia: Developmental Opportunity or Deepening China's New Mercantilism?”. 
tries? "Where the money goes"? In other words, "How and why China became Africa's biggest aid donor"? ${ }^{119}$

China's 2011 "white paper on foreign aid" shows "where the money of the China's Foreign Development Aid goes" as follows: “The main areas of support for China has been in projects in agriculture, industry, economic infrastructure, public facilities, education and medical and health care, with the intent on improving recipient countries' industrial and agricultural productivity, laying a solid foundation for their economic and social development, and improving basic education and health care." ${ }^{120}$ [...] "China's aid in sub-Saharan Africa is varied and can be found in almost all sectors from telecommunication to health. The largest amount of aid funding goes towards the transport, storage, energy and communications sectors. A significant share, about $70 \%$, is geared towards infrastructure development." 121

Henry Gray comments on the China's Foreign Development Aid Policy consequently: "China seems like a wonderful and empathetic nation reaching out and helping other countries realise their potential". ${ }^{122}$

Therefore, the controversial discussions and debates on the negative impacts of the Foreign Development Aid Policy of the Western world for the Third World Countries for instance for the African countries which are already discussed in this Research Paper are now proved by the contribution of the China's Foreign Development Aid Policy to the economic, social and environmental development of the African countries like Ethiopia in a very short of time, i.e. within 10 years.

Therefore, it is irony that the Western world denoted China's engagement in Africa as "plundering African resources" and blaming that 'China is practising new colonialism and "raw material imperialism" in Africa. ${ }^{123}$

\subsection{Research Questions}

As already stated above "Foreign Aid" means transferring of goods or services from one country to another country. This means, from developed countries to developing countries (Third World Countries) for example from the United

\footnotetext{
${ }^{119}$ Source: The conversation.com/how-and-why-china-became-africas-biggest-aid-donor-57992, Apr $26,2016$.

${ }^{120}$ Source: "White paper: China's foreign aid"-China Daily (2011) Updated: 2011-04-22: www.chinadaily.com.cn/cndy/2011-04/22/content_12373944.htm

121"The Conversation Academic rigour, journalistic flair" "How and why China became Africa's biggest aid donor": the conversation.com/how-and-why-china-became-africas-biggest-aid-donor-57992, April 26, 2016 6.28am SAST".

${ }^{122}$ Gray (2016) "is a Friend of "The Conversation" (source): "How and why China became Africa's biggest aid donor".

123"A Nigerian listener of China Radio International programs commented in his email, 'The Western accusation about China's so-called new colonialist ambitions are sheer jealousy and prejudice for the fact that China has cooperated with African countries, generously provided technical assistance, and helped African countries to break the Western imposed chains of exploitation and unfairness'. Source: Guimei (2010): “China and Africa: Mutual Benefit and Win-Win: "Institute of Western Asian and African Studies, Chinese Academy of Social Sciences", 2010-06-18 Guangming Daily.
} 
States of America and Europe to the African countries for instance to Ethiopia.

But the question is, what kind of goods or services are transferring and from where to where?

Who transfers goods or services?

How much the Western world transfers goods and/or services to Africa comparing to that Africa transfers to the Western world?

\section{Therefore, who helps whom?}

\subsection{Objectives}

Generally, the objective of a research should fulfill one of the following criteria or aim:

- To fulfill a research gap or

- To find out an answer or a solution for a problem or

- To disprove a theory or

- To acquire new knowledge

Therefore, the researcher of this Research Paper wants to contribute to:

1) The enlightenment of the assumptions of the citizens in the Western world that "Foreign Development Aid" is not contributing to "help for self-help" in the Third World Countries for instance in Ethiopia.

2) Raise awareness of the citizens of the donor countries to consider their assumptions and check the reality on the ground, what happens to their money (donations and taxes), otherwise the doors of corruptions are wide open with their donations and taxes in their countries as well as in the Third World Countries for example in Africa.

3) A discussion on the real causes of poverty and/or food insecurity in Africa for example in Ethiopia.

The poverty especially, food insecurity in many African countries for instance in Ethiopia is because of "man-made" problems.

This means, as already noted above, Africa is the second largest continent in the world with huge agricultural, mineral and human resources that it could feed the whole world. Even Ethiopia is a big country, as already mentioned above that it could feed the African continent, as many experts certify. But unfortunately, the reality today on the ground shows the opposite. Therefore, this paradox situation should be solved.

\subsection{Hypotheses}

The fact that "Foreign Development Aid" is not altruistic to help poor people in the Third World Countries for example in Africa, i.e. it is not "help for self-help" from the humanitarian aspect.

"Foreign aid has done more harm to Africa than we care to admit. It has led to a situation where Africa has failed to set its own pace and direction of development free of external interference. Today, Africa's development plans are drawn thousands of miles away in the corridors of the IMF and World Bank. What is 
sad is that the IMF and World Bank 'experts' who draw these development plans are people completely out of touch with the local African reality". ${ }^{124}$

Therefore, "Foreign Development Aid Policy" of the Western world may not be realized in the Third World Countries for instance in the African countries, because "help for self-help" means to enable developing countries to process their own agricultural and mineral resources in their own countries and this could have negative consequences on the economic development of the Western countries.

In other words, many industrialized economies like Germany, Japan, the Netherlands, etc. depend on the mineral and agricultural resources of the Third World Countries for instance of Africa, these industrialized countries may face economic and social problems.

1) "Where there's a will, there's a way". This means, if the foreign Governmental and Non-governmental Organizations are determined enough to solve the economic, social and environmental problems of the African countries for instance of Ethiopia, they can find a way to achieve what these countries need. Because the Governmental and Non-governmental Organizations have the knowledge, the means or capacity, concepts, and "strategy objectives" how to solve the problems for the sectors in which they are engaged in the Third World Countries for example in Ethiopia but unfortunately, they do not want to solve the problems of these countries due to interest conflicts.

2) "Foreign Development Aid" is myth which serves as a means of preserving the existing economic and social structures, i.e. privileges in the world. In other words, the industrialized countries are protecting their economic, political and military hegemonies with the help of "Development Aid Policy".

3) There are obstacles to solve the problems in the Third World Countries for instance in Africa but these obstacles haven't only "exogenous" factors but also they have "endogenous" 125 factors. For example, poverty especially, food insecurity in many African countries for instance in Ethiopia has "endogenous" factors, i.e. "Dependency Mentality"126 of many governments and also societies in many African countries.

4) Impacts of "Foreign Development Aid":

a) The researcher of this paper is convinced that "Dependency Mentality" is the reason for the continuity of "Foreign Development Aid" in Africa for instance in Ethiopia.

b) "Foreign Development Aid Policy" continues to create dependence instead of self-sufficiency in many parts of the world. One country affected is Ethiopia, where poverty and hunger remain rife despite very fertile soil and decades of development aid. However, recipient countries like Ethiopia should accept part of the blame for the continuity of this dependency.

c) USAID, German Federal Foreign Office and GIZ do not have scientific evi-

\footnotetext{
${ }^{124}$ Karanja (1992) “a former Kenya member of parliament, in New African”.

${ }^{125} \mathrm{Having}$ an internal cause or origin.

${ }^{126}$ When people expect everything from others for their life.
} 
dence that "rapid population growth" in Ethiopia is the cause or hindrance for economic growth and the cause for environmental problems for instance for soil erosion as they say repeatedly. But they reflect only the opinion of the Malthusian and Neo-Malthusian hypothesis which says: population growth causes economic, social, political unrest and environmental problems. Thomas Robert Malthus had published his Essay on Population Growth (1798). In it he argued that population multiplies geometrically and food arithmetically; therefore, the population will eventually outstrip the food supply. However, this hypothesis of Malthus was not realized neither in the UK nor in other Western countries. But the followers of Malthus, i.e. the Neo-Malthusians say that the hypothesis of Malthus happens in the Third World Countries today.

d) Whatever the motives of "Foreign Development Aid" were and are, Development needs first Development Factors. For example: There cannot be Sustainable Peace and Sustainable Development Achievement without Development Factors like Law and Order and Ethical

Principles like Accountability, Responsibility, etc.!

\section{Literature Review}

The researcher of this Research Paper has evaluated the literature on the basis of theoretical and practical significance in order to find out scientific facts behind the controversial debates and discussions on the impacts of "Foreign Aid in Sustainable Development" in the Third World Countries as an example of the African countries like Nigeria, Democratic Republic of Congo (DRC) and Ethiopia.

As already stated in the Introduction section of this Research Paper there are two groups who argue pros and cons ("pro et contra") about the impact of "Foreign Development Aid" for example in Africa, in the case of Ethiopia.

As already described above, the following scholars are against the current practice of the "Foreign Development Aid Policy" for the Third World Countries for example for Africa.

\section{For example:}

- Brigitte Erler: describes Foreign Aid for the Third World Countries as "dead aid".

- James Shikwati says: "Stop Foreign Aid, it is killing Africa."

- Dambisa Moyo describes Foreign Aid in Africa as "Dead Aid". Moyo's book "Dead Aid" reveals that millions are actually poorer because of foreign aid.

- Edrine Habasa and Nathan Andrews describe the impact of foreign aid in Africa in their articles as follows: Habasa says: "Foreign aid is a modern joystick used to play a modern game called the African economy! Have African economies been hijacked? It is an undeniable fact that foreign aid has extensively, intensively and forwardly steered the economies in Africa's countries." The other group who argues for the continuity of "Foreign Development Aid Policy" is as follows:

- Jon Benjamin from United Kingdom Foreign \& Commonwealth Office sup- 
ports foreign aid. He says: "Why do we do this? Because we believe it's the right thing to do, both morally as a good global citizen and, in this case, because of the responsibilities we take from our own history and colonial involvement in Africa."

- As already stated above, also Charles Abugre supports Foreign Aid due to ethical aspects as follows: He asks: "Why foreign aid is important for Africa: The idea that those who have should share with those who don't is inherent in most societies-insects, animals and humans alike. Sharing is essential to maintain and protect the collective, and empathy is an essential value of what it is to be human." 127

However, the criticisms are not against the principles of "Foreign Development Aid" in general but rather the current practices of the Foreign Aid Policy on the ground for instance in the African countries like in Ethiopia in particular. In other words, there is nothing wrong with the principles of "Foreign Development Aid" if their aim is based on Help to Self-Help, Mutual Respect and Mutual Benefit, equality between partners, respect for sovereignty. According to the literature, "China has been providing aid to the best of its ability to other developing countries with economic difficulties, and fulfilling its due international obligations." ${ }^{28}$

However, the question is, what are the differences between the "Development Aid Policies" of the Western world on one hand and of China on the other hand for instance towards Africa?

The reasons why China has managed to help the African countries for instance Ethiopia in a short period of time, i.e. within 10 years, in contrast to the Western world more than 60 years are, as already discussed above, that the "Foreign Development Aid Policy" of the Western world is not based on Help to Self-Help, Mutual Respect and Mutual Benefit like the China's Foreign Development Aid Policy. Because China's Foreign Development Aid Policy was premised on equality between partners, mutual benefit, respect for sovereignty, respect for obligations and enhancing the self-reliance of Chinese aid recipients. ${ }^{129}$

As already described in the Introduction section of this Research Paper there is another group of scholars who describes Africa as a rich continent in general and Ethiopia in particular.

For example:

- Marietta Slomka said that Africa is not poor, then it has breath-taking incredible landscape, almost inexhaustible important reserves of natural resources and fertile land (fertile soils) that Ethiopia alone could feed easily the whole continent of Africa. Because Ethiopia is a big and very fertile land. Consequently, Slomka asks: "Who gets the benefit of the immense richness of the continent?"

\footnotetext{
${ }^{127}$ Abugre (2010) Special to CNN.

${ }^{128}$ Source: China's Foreign Aid (2011): Information Office of the State Council: The People's Republic of China.

${ }^{129}$ Jalata (2014): "Development Assistance from the South: Comparative Analysis of Chinese and Indian to Ethiopia”, Chinese Studies -Scientific Research Publishing, Vol. 03 No. 01 (2014).
} 
- Calestous Juma said about the fertile land of Ethiopia that [...] Ethiopia has more than 74 million hectares of cultivable land. So far, only 15 million is cultivated. Bringing three million hectares of land into cultivation in the coming four years is a modest step in the country's effort to foster economic transformation and does not represent misguided land allocation".

- Also "The New York Times" report shows that Ethiopia has one of the most fertile lands in the African continent. It has the potential to become the "food basket of the world".

This means that this group supports indirect the critics of the current Foreign Aid Policy practice because Africa is rich, i.e. Africa doesn't need such Foreign Aid.

Accordingly, the author of this Research Paper would like to support the critics of the current Foreign Aid Policy practice on the ground because today African countries are more dependent on foreign aid although they are rich in natu$\mathrm{ral} / \mathrm{mineral}$, agricultural and human resources.

The fact that the economic, social and environmental problems of the above mentioned African countries like Nigeria, Democratic Republic of Congo (DRC) and Ethiopia are not yet solved, despite their huge resources the interest of the researcher of this Research Paper is to find out the real causes of these problems on the ground for example in Ethiopia.

As already noted above Bi-lateral and Multi-lateral Organizations like for example USAID has provided assistance to Ethiopia since its inception in 1961 as follows: "Since 1961 the USAID provided assistance in: Agriculture: Agriculture and Food Security: Through Feed the Future, USAID enhances food security, increases agricultural productivity, and promotes resilience, especially among vulnerable populations."

USAID has documented in its annual report under the title "EVOLUTION OF USAID OBJECTIVES IN ETHIOPIA" about the situation in Ethiopia from 1962 up to 2013/2014 with "Strategic Objectives". But unfortunately, there is no solution even for the food insecurity in Ethiopia. ${ }^{130}$

As already described above, there are many Non-Governmental Organizations which are under the umbrella of the Consortium of Christian Relief and Development Association (CCRDA) in Ethiopia. According to its source, CCRDA is an association of non-governmental and civic society organizations that lobby for poverty alleviation and policy advocacy. Although CCRA was founded in 1973 in response to famine in Ethiopia, it did not prevent the famine in Ethiopia let alone to solve the food insecurity, despite its activities include urban and rural development with an emphasis on food security, health education, HIV/AIDS awareness, water and sanitation, good governance, environmental protection, and civic education.

\footnotetext{
${ }^{130}$ Source: website: USAID:CBJ FY 1962: usaid.gov/pdf docs/PNAAX630.pdf) October 25, 2011; September 12, 2012; December 18, 2012; February 7, 2013; January 31, 2014, Last updated: December 22, 2014.
} 
Moreover, there is a cooperation between CCRDA and USAID concerning their mission in Ethiopia as the Acting Deputy Mission Director Elise Jensen of USAID said on November 28, 2014 on the Annual Membership Assembly CCRDA. $^{131}$

As already noted above the German Federal Foreign Office (Auswärtiges Amt) and the GIZ argue the same as USAID that rapid population growth in Ethiopia is the cause or obstacle for economic growth and the cause for steady soil erosion. The German Federal Foreign Office said further that also lack of resources is a cause of the structural problems in Ethiopia.

Therefore, such problems remain unresolved despite huge efforts. ${ }^{132}$

The fact that there is no evidence for the arguments of USAID, German Federal Foreign Office and GIZ that "rapid population growth" in Ethiopia is the hindrance for economic growth and the cause of soil erosion.

The researcher of this paper has discussed on the hypothesis of the Neo-Malthusian scholars as well as on the hypothesis of the Anti-Neo-Malthusian scholars in this Research Paper concerning the impact of population growth. Therefore, this Research paper has already found out the real causes of the economic, social and environmental problems in Ethiopia, i.e. man-made problems (see e.g. of the Ethiopian Federal Auditor report).

But the question is, where do the Neo-Malthusian scholars get the Ethiopian population figures or sizes without any infrastructure to conduct population census or institutions like Municipality or districts who can register:

- birth rate

- death rate

- internal migration and

- emigration (external)

Fact is the Ethiopian government had announced on $4^{\text {th }}$ August 2016 to launch nationwide vital events registration system in Ethiopia for the first time in the history of the country. ${ }^{133}$

As already described above, not only population growth is not reliable but also the majority of the other reports of the Governmental and Non-Governmental Organizations as well as of the mass media about Ethiopia are one-sided, biased and sensational. For example, they exaggerate the number of people who need help and make headlines with horror photos, especially of children although they do not help what they promise. The result of such sensational news has negative image for the countries like for example Ethiopia that neither investors nor tourists have confident in these countries. Take for example the German feature film which was produced in Ethiopia with the actor Jürgen Vogel for the German TV and introduced by the ARD-boulevard magazine "Brisant" that the TV-Moderator Kamilla Senjo ${ }^{134}$ said that this film was produced in Ethiopia in

${ }^{131}$ Source: berkleycenter.georgetown.edu/.../consortium-of-christian-relief-and-developm.

${ }^{132}$ German Federal Foreign Office/Deutsches Auswärtige Amt (2013): Wirtschaft Äthiopiens, Stand: März 2013 and GIZ_Äthiopien https://www.giz.de/de/weltweit/

${ }^{133}$ See Ethiopian Broadcasting Corporation/ETV on $4^{\text {th }}$ August 2016 and "The Ethiopian Herald" newspaper on $5^{\text {th }}$ August 2016, No. 282, page 1 and 2. 
which one of the poorest countries in the world.

Therefore, the question is, why this TV-Moderator describes Ethiopia as the poorest country of the world although the reason to produce the film in Ethiopia has nothing to do with the poverty of the country? In fact part of this film was produced in Germany.

Couldn't this moderator affiliate Ethiopia with other positive characteristics of the country rather than negative images?

\section{Should be Ethiopia associated always only with civil war and poverty?}

Whatever the purposes of propagating such negative images against African countries like Ethiopia are, the consequences are devastating as Erich Wiedermann described under the title "Helping the Hungry: Addicted to Aid in Ethiopia" as follows: "Many Ethiopians are kept alive by the world's generosity. But addiction to food aid has also virtually wiped out any semblance of self-reliance in the country. Much of the economy relies on foreign aid, and the government sees no reason to change things. ${ }^{135}$

As already described above, there are internal and external development factors in a country like Ethiopia. Therefore, the researcher of this paper is convinced from his experiences in Ethiopia in different regions that resources mismanagement is the main factor for economic, social and ecological problems in Ethiopia as the following two cases show clearly.

\subsection{Case Study: Example I}

Here are some examples of empirical findings of the researcher of this paper during his journey from Ambo (western Ethiopia: Ambo-Addis Ababa: 126/114 $\mathrm{km}$ ) to Assosa (the capital city of Benshangul Gumuz/Regional State of Ethiopia) from 28.04.2016 - 02.05.2016 (Ambo-Assosa: $548 \mathrm{~km}$ ):

- The districts starting from Ijaji to Bako (not far from Ambo) are covered by Mango trees but not well-managed, i.e. the mango trees look like as wild trees. This means the Mango trees are not cultivated.

- The next districts (after Nekemte, the capital city of Wollega/Oromia State Region) up to the border between Oromia State Region and Benshangul Gumuz which are covered by Mango Trees. In these areas, Mango Trees were planted not only in the fields or compounds of the farmers but also along the roads like eucalyptus trees (wild mango trees). I was asking myself, whose mango trees are along the roads?

But unfortunately, also these mango trees are not well-managed as they should be because they could be also a source of income for the owners or small farmers.

In some areas on the way to Assosa for instance Mendi, Ghimbi, Nejo, the researcher of this paper has observed not only mango but also coffee, papaya, avocado, honey/bees (with traditional beehives). Moreover, these areas have water, i.e. small and medium rivers. But these rivers are also not well-managed al${ }^{134}$ TV-Moderator Kamilla Senjo (21.12.2016).

${ }^{135}$ Wiedemann (2005): “In Addis Ababa, Ethiopia, Spiegel Online International”. 
though there are many possibilities to use them, for instance for irrigation.

Assosa: (I should call it) "A City of Mango". Almost in every house's compound (residence, hotels, and other institutions) there are many mango trees with plenty of mango fruits. The fruits are so sweet that I did not have an appetite for other food except mango.

But unfortunately, the disease has attacked not only mango trees but also banana trees. The researcher of this Research Paper has observed the above-mentioned areas (from Ijaji to Assosa) while he was traveling from Ambo to Assosa on 28.04.2016 and from Assosa to Ambo on 02.05.2016.

This reality shows that nobody takes care of the sustainable development of the natural resources in Ethiopia.

But the question is, what will happen to these natural resources in Ethiopia after some time if the concerning institutions and or persons do not take immediate action against the degradation or depletion of these resources?

Why do the Ethiopian government and the international Governmental and Non-Governmental Organizations like USAID and GIZ focus only on birth control to reduce poverty?

Which one is easier and better: To avoid the diseases of mango or the birth of a child?

What is the opinion of the Neo-Malthusian scholars about the above mentioned areas which are rich but the people are poor?

Should the farmers get few (two) children in order to cure the mango trees from diseases and they can get better price for their mango fruit and cultivated the mango field by itself?

\subsection{Case Study: Example II}

One case study (empirical study) of the researcher of this paper in Ambo District shows the paradox situation in Ethiopia more clearly and could be an exemplar for many Third World Countries for instance for African countries. The name of the farming area is Awaro (Gerimelke) in Ambo District.

The poor farmers of this district have problems with their crops like carrot, tomato, pepper etc. because these crops are destroyed by bacterial disease (fungal disease) and insects every season. These farmers use neither fertilizer nor chemical substance to protect their crops whereas rich farmers around this area use fertilizer as well as pesticides to protect their crops from different diseases and insects.

In addition to the fungal disease, the crops of these poor farmers are attacked by a very strong weed which has very, very long roots, many branches and it is also very big. This weed rolls the crops so that the crops can't grow and also can't be seen that they are there. It seems like a type of grass but it is a very strong plant.

The researcher of this paper has visited the above-mentioned area on 03.12.2015 and on 30.03.2016 with his colleagues (scientists from different facul- 
ties) of Ambo University. This area is about $10 \mathrm{~km}$ far from Ambo University.

It is incomprehensible to the researcher of this paper why research institutions of the Federal Ministry of Agriculture have offices in Ambo and Bako if they are not interested to solve the problems of the farmers in these areas?

Moreover, the Ethiopian government hopes that the establishment of universities almost in every small town in order to solve the problems of the regions. According to the Ethiopian government currently there are 33 universities and 11 are in building.

But the paradox is that the problems which are noted above (case I and case) are known to many faculties of Ambo University.

Therefore, the question is, if the Universities of Wollega, of Ambo or of Assosa or the federal research institutions are not interested in taking actions to solve such problems, then what is the meaning of establishing new universities every year and in every village for the people?

Therefore, the main reason for poverty in Africa as an example in Ethiopia is the negligence of small farmers and traders as well as handcraftsmanship. Nobody takes care of small crop farmers, coffee and fruit farmers as well as small traders for example in Chicko District in the southern part of Ethiopia and fruit farmers for example in the Districts starting from Ijaji/Bako up to Assosa in the western part of Ethiopia.

The researcher of this paper has traveled from Ambo to Assosa on 28.04.2016 and from Assosa to Ambo on 02.05.2016 (see below for more details). Small farmers and small traders do not have the capacity to expand their business and that is why they do not get facilities like fertilizer, credit or loan, market access, transportation, storage, support during disaster relief or emergence aid, etc.

Despite all the huge resources, Ethiopia is one of the poorest countries in the world.

Hence, the big question is, why can't Ethiopia feed itself although this country has huge potential richness or capacity even to feed the African continent?

Another reason of the paradox situation of Ethiopia but also of Africa is begging. Because begging is easier for many governments and also many societies in Africa instead of making efforts in order to be independent from aid.

It is cynical but the Ethiopian government and the international Non-Governmental Organizations focus only on birth control to reduce poverty?

But which one is easier and better: To avoid the diseases of mango or the birth of a child?

Who told the Ethiopian government that birth control is the solution to solve poverty?

As already discussed above Ethiopia needs help or support only to manage, i.e. to organize, to coordinate and utilize its vast and huge natural, agricultural and human resources but not birth control as the solution of these problems.

However, despite all these facts Governmental and Non-Governmental international organizations like for example USAID and GIZ focus only on birth control to "reduce poverty and civil war" also in the DRC today. 
But the question is which one is easier and better: To avoid the civil war or the birth of a child in the DRC?

What is the opinion of the Neo-Malthusian scholars about the above mentioned problems of the DRC that this country is extreme rich in natural and agricultural resources but the majority of the people are poor because of the civil war?

\subsection{Method of Data Collection}

The researcher of this paper wants to find out scientific facts behind the debates and discussions on "Foreign Development Aid" as well as its impacts on psychological, political, economic, social, and cultural developments in the Third World Countries, i.e. dependency ${ }^{136}$ on the Western world.

Therefore, the researcher of this paper has applied the following methodologies including empirical findings and observations during his journey from Ambo to Assosa (from 28.04.2016 - 02.05.2016.). Therefore, two case studies were conducted in Ambo District and in other Districts of western Ethiopia:

- One case study was to test the different hypotheses of poverty, i.e. about the causes of poverty on the ground in the selected location study areas (Ambo District) and

- The other case studies or observations were conducted in the following some selected areas in western Ethiopia.

1) After collecting the secondary data from various sources such as historical and present publications, records, regulations, laws, reports, etc. of both governmental and non-governmental organizations in Addis Ababa are reviewed.

2) The selected different locations and study areas are Ambo District (western Ethiopia). Ambo is about $114 \mathrm{~km}$ far away from Addis Ababa. The other districts are Chicko in the southern part of Ethiopia, Ijaji/Bako (western part of Ethiopia)), Mendi, Ghimbi, Nejo. All these districts are in Oromia State Region in western Ethiopia. The next location is Nekemte, the capital city of Wollega/Oromia State Region in western Ethiopia. Another study area is Assosa (the capital city of Benshangul Gumuz/Regional State of western Ethiopia).

Therefore, the main purpose of these data collections is to find out scientific evidence that serves to either support or to disprove a scientific theory or hypothesis of poverty in Africa as an example of Nigeria, Democratic Republic of Congo (DRC) and Ethiopia.

\section{Significance of the Study}

The goal of this Research Paper is to contribute to:

- The clarification about the real causes of poverty, depletion of natural resources and environmental problems in the African countries but especially

\footnotetext{
136" Dependency theory is the notion that resources flow from a "periphery" of poor and underdeveloped states to a "core" of wealthy states, enriching the latter at the expense of the former. Dependency theory originates with two papers published in 1949-one by Hans Singer, one by Raúl Prebisch.
} 
in Ethiopia.

- enlightenment of the assumptions of the citizens in the Western world that "Foreign Development Aid" is not "help for self-help" in the Third World Countries for instance in Ethiopia but the contrary.

- In this article, the researcher adds to the recent and limited micro level evidence on the impact of the international Governmental and Non-Governmental Organizations in Africa for instance in Ethiopia.

- This article provides insights for African or international researchers about the impact of the international Governmental and Non-Governmental Organizations in Africa for instance in Ethiopia.

- This study is important to suggest that "Foreign Development Aid" is not altruistic.

- As already stated in the above parts of this research project, this problem affects almost all the societies, i.e. in the donor countries as well as in the recipient countries. Therefore, the benefits of this research work are for all stakeholders.

- Therefore, this study is significant for further studies to be made in the reasons behind the "Foreign Development Aid" in Africa for example in Ethiopia.

\section{Scope of the Study}

The researcher of this Research Paper has studied the impact of the international Governmental and Non-Governmental Organizations in Africa for instance in Ethiopia also through work experiences and empirical observations. The study has compared the reality on the ground and the potential capacity of the African countries for instance of Nigeria, Democratic Republic of Congo (DRC), Ethiopia etc.

\section{Limitation of the Study}

The first limitation of this study is that the methodology used fails to investigate the impact of the international Governmental and Non-Governmental Organizations in other Africa countries in detail like in Ethiopia. The other limitation is that the researcher of this Research Paper could not find enough current references about the impacts of the international Governmental and Non-Governmental Organizations in the African countries in detail.

Although the study of this Research Paper doesn't cover the entire continent of Africa, the same conclusion can be drawn to the entire continent because the "Foreign Development Aid Policy" of the Western world for the Third World Countries is the same also for the African countries like for example for Ethiopia.

\section{Results}

Now it is undeniable fact that Foreign Development Aid can contribute to "help for self-help" if it is based on Help to Self-Help, Mutual Respect, Mutual Benefit, 
equality between Partners, Respect for Sovereignty, Respect for Obligations and enhancing the Self-Reliance like the China's Foreign Development Aid Policy which is contrary to the "Foreign Development Aid Policy" of the Western world.

The reasons why the "Foreign Development Aid" of the Western world didn't contribute to the solutions of economic, social and ecological problems of the Third World Countries for example of Ethiopia are:

1) The aim of the "Foreign Development Aid Policy" of the Western world is not to "help for self-help" in the Third World Countries for example in Ethiopia,

2) The Non-Governmental Organizations of the Western world are the beneficiaries of the "Foreign Development Aid Policy" of the Western world in the Third World Countries for example in Ethiopia. In other word, there is a conflict of interest.

As already discussed above many experts like Linda Polman, the former Ethiopian Prime Minister Meles Zenwai, James Shikwati, Erich Wiedermann describe the engagement of many NGOs in Third World Countries for example in Ethiopia as "aid as business" or as "aid industry". Shikwati says that the NGOs are self-seeking, because they collect money for themselves and they are engaged in pure business. He said further that instead of helping poor people the NGOs propagate negative images or impressions against Africa and create fear and tension that tourists and investors stay away.

Another result of this research project shows that there is no reliable population statistics and population growth because there is no infrastructure or registration system in order to know the world population growth in thousands and in millions per second, per minute, per hour, per day, per month or per year.

Nobody knows exactly how many people live on the earth planet today let alone to know the population growth of a country like Ethiopia, Nigeria or Bangladesh every second, every minute, every hour, every month or every year. Despite the problems of infrastructure, the United Nations Population Report shows that the world population has reached 7 billion in October 2011 by 7.2 billion in 2013. According to the UN projection, the world population will reach 8.5 billion by 2030, 9.7 billion by 2050 and exceed 11 billion in 2100 driven by growth in developing countries. ${ }^{137}$

But many international organizations or institutions, journalists, academicians, and politicians quote the United Nations Organization (UNO), in order to make their statements trustful in the public. However as everybody knows the UN does not have any means to count the population of a country like Ethiopia unless and otherwise the Ethiopian government conducts a population census. But unfortunately, this is not possible in Ethiopia without the infrastructure for the accurate population census.

As already noted above there no evidence for the statements of USAID, German Federal Foreign Office (Auswärtiges Amt) and the GIZ that "rapid population growth" in Ethiopia is the cause of poverty and environmental problems for ${ }^{137}$ See the UN website and UN Photo/Eskinder Debebe. 
instance for soil erosion and hindrance for economic growth.

Therefore, USAID, German Federal Foreign Office (Auswärtiges Amt) and the GIZ advocate simply the same hypothesis of the Malthusian and Neo-Malthusian scholars which says: population growth has a negative impact on economic, social and environmental developments in the Third World Countries for example in Ethiopia.

However, the question is, why these organizations see "rapid population growth" in Ethiopia as the cause of poverty and environmental problems for instance for soil erosion and hindrance for economic growth but not corruption, rent seeking especially of governmental institutions and the business community in Ethiopia (see above: Federal Auditor Report) as hindrance for development of the country?

\section{Discussions}

As already noted above, many experts have criticized the practice of "Foreign Development Aid Policy" of the Western world but unfortunately the donor countries ignore all criticisms.

But the question is, why the donor countries ignore the criticisms of many experts also some of the experts are from the donor countries?

As already discussed above, the Western world denies the realities on the ground that China has managed to help the African countries for instance Ethiopia in a short period of time, i.e. within 10 years, in contrast to the Western world more than 60 years, because the "Foreign Development Aid Policy" of the Western world is not based on Help to Self-Help, Mutual Respect and Mutual Benefit like the China's Foreign Development Aid Policy. Because China's Foreign Development Aid Policy was premised on equality between partners, mutual benefit, respect for sovereignty, respect for obligations and enhancing the self-reliance of Chinese aid recipients.

The Western world covers up the facts on the ground in the World countries for instance in Ethiopia. For example as already stated above, Ethiopia is referred as "water tower" or "the mother of water" because it has large number of rivers and lakes but USAID has said in its report in 2013/2014 that there is low percentage of land irrigation in Ethiopia.

But the question is, what are the reasons for the low percentage of land irrigation in Ethiopia and what is the duty of USAID, GZ and co. if they do not solve such problems? What is their mission?

Why couldn't USAID solve the problem of "Market linkages and the use of improved seeds, fertilizers and pesticides" in Ethiopia since 1961?

As already noted above the German Federal Foreign Office (Auswärtiges Amt) said that also lack of resources in Ethiopia is a cause of the structural problems. Therefore, as the German Federal Foreign Office further said that such problems remain unresolved despite huge efforts.

The question is, what kind of resources lacks Ethiopia to produce food? Why 
couldn't the German Government helps Ethiopia to solve the food insecurity? Ethiopia has all resources except responsibility and accountability of its leaders.

How do USAID, the German Federal Foreign Office (Auswärtiges Amt) and the GIZ explain the reports of Marietta Slomka, Volker Seitz and the New York Times (see above)?

As already explained above, Marietta Slomka said that Africa is not poor, because it has "breath-taking incredible landscape, almost inexhaustible important reserves of natural resources and fertile land (fertile soils) that Ethiopia alone could feed easily the whole continent of African."

Also Volker Seitz said about the paradox of Africa that the continent has abundant resources which are almost "unimaginable quantity and it has diverse cultures."

Therefore, Slomka asks: "Who gets the benefit of the immense richness of the African continent?"

\section{Conclusion}

The researcher of this Research Paper would like to conclude his research as follows:

- As already explained above, the "aim" of the Foreign Development Aid Policy "help for self-help" for the Third World Countries for example for Ethiopia did not be materialized, i.e. "Foreign Development Aid Policy" for the African countries for example for Ethiopia causes more dependency and paralyses in these countries.

- This dependency and the paralysis situation in the Third World Countries for instance in Ethiopia are the purpose of the "Foreign Development Aid Policy" because the mineral and agricultural resources for example in Africa are need in the "donor" countries for the process of their economy.

- However, not only the "donor" countries or "Foreign Development Aid Policy" are to blame for more dependency and paralysis in the African countries for example in Ethiopia but also the responsible governments as well as the society in the African countries for example in Ethiopia.

- The Governmental and Non-governmental Organizations of the Western world have the knowledge, the means, concepts, and "strategy objectives" how to solve the problems for the sectors in which they are engaged in the Third world countries for example in Ethiopia but unfortunately, they do not want to solve the problems of these countries due to goal conflict.

- Therefore, "Foreign Development Aid" is a myth which serves as a means of preserving the existing economic and social structures, i.e. privileges in the world. In other words, the industrialized countries are protecting their economic, political and military hegemonies with help of "Development Aid".

- Also the discussions and debates about "overpopulation" in the Third World Countries serve as a means of preserving the existing economic, social and political structures in the world. ${ }^{138}$ 
- However, the obstacles of the solutions for the problems in the Third World Countries for instance in Africa have not only "exogenous" factors but also "endogenous" factors.

- The answer for the principal question, how many humanitarian and development aid organizations does a country like Ethiopia need, depends on the situation and capacity of the recipient country on one hand and the genuine purpose of the donor countries on the other hand.

Therefore, the controversial discussions and debates on the negative impacts of the Foreign Development Aid Policy of the Western world for the Third World Countries for instance for the African countries which are already discussed in this Research Paper are now proved by the China's Foreign Development Aid Policy that "Foreign Development Aid" is not negative in principle, i.e. it depends on its aims. As already stated above, the China's Foreign Development Aid Policy is based on Help to Self-Help, Mutual Respect, Mutual Benefit, equality between Partners, Respect for Sovereignty, Respect for Obligations and enhancing the Self-Reliance of Chinese aid Recipients which is contrary to the "Foreign Development Aid Policy" of the Western world.

\section{Recommendations}

The author of this Research Paper would like to recommend the Governmental and Non-Governmental Organizations especially of the Western world to revise their "Foreign Development Aid Policy" (ODA) for the Third World Countries for instance for the African countries as an example Ethiopia. It would be better for the Governmental and Non-Governmental Organizations of the Western world to learn from China's Sustainable Development Aid Policy ("Mutual Benefit of Development Policy") in Africa, in the case of Ethiopia if they want to participate in the development process of Africa and secure their economic, social and political instabilities of their countries in the present and in the future as well.

The decisive factors for the development of Africa is only when the governments and the societies of Africa for example of Ethiopia learn to stand on their own feet. The societies need a process of rethinking just now before it is too late. In fact it is already "five minutes to twelve." But awareness and consciousness should come first and foremost because these are decisive factors for development. Especially the small farmers in Ethiopia need enlightenment or clarifications how to utilize their land, for instance simple information about crop and vegetable rotations and to be aware of harvesting time. The other point what the small farmers need to know is the advantages of new technologies for example using biogas, compost, crop rotation, etc.

Last but not least: Development Aid should follow the following principles:

A proverb says: "Give a man a fish and you feed him for a day; [but] teach a man how to catch a fish and you feed him for a lifetime." The ancient Chinese

${ }^{138}$ Abeselom (1995). 
proverb has long been a guiding principle of international development aid.

\section{Acknowledgements}

I would like to express my sincere thanks to Mr. Abby Ogbazghi. Has provided me a comfortable working place with full infrastructure and catering in his house to write this research paper. I would like to give also special thanks to Professor Dr. Guido Hausmann for his continuous supports in different aspects. Last but not least, I would like to thank family Streber for providing me accommodations during my stay in Germany.

\section{Conflicts of Interest}

The author declares no conflicts of interest regarding the publication of this paper.

\section{References}

Abeselom, K. (1995). Der Mythos der Überbevölkerung als Mittel zur Wahrung der bestehenden gesellschaftlichen Strukturen. Die theoretischen Grundlagen der UNO-Bevölkerungspolitik: malthusianische und neo-malthusianische Wurzeln.

Abeselom, K. (2017). The Reasons behind the Debates and Discussions on Population Growth: Positive or Negative Impacts on Economic, Social, Political, Natural Resources and Environmental Developments.

Abiye, Y. (2017). Audit Report Irks Lawmakers. In The Reporter Armyworm Spreads Danger to 6 Maize Growing Regions in Ethiopia. Beijing: Xinhua.

Abugre, Ch. (2010). Special to CNN.

Andrews, N. (2009). Foreign Aid and Development in Africa. Academic Journals, 1, 008-015.

ARD-Tagesschau [German Broadcaster News] (2012). "Foreign Conspiracy" to Destabilize and Weaken Egypt. Hamburg: ARD-Tagesschau.

Astier, H. (2006). London: BBC News Website.

Ayittey, G. B.N. (1992). The Myth of Foreign Aid.

Barder, O. (2009). Aid Effectiveness, Development, NGOs, Politics-Ethiopia's New Civil Society Law-Owen Abroad. Addis Ababa. http://www.owen.org/blog/2086

BBC World News (2016). London: BBC World News.

Benjamin, J. (2015).

Blair, E. (2016). Short of Food in Ethiopia.

China Daily (2011). White Paper: China's Foreign Aid.

http://www.chinadaily.com.cn/cndy/2011-04/22/content_12373944.htm

China's Foreign Aid (2011). Beijing: Information Office of the State Council.

Clark, J. (2000). Civil Society, NGOs, and Development in Ethiopia A Snapshot View. T Washington DC: The World Bank.

Daily Nation (2009). Nairobi: Daily Nation.

Desta, A. (2009). Chinese Investment in Ethiopia: Developmental Opportunity or Deepening China's New Mercantilism?

Deutsche Botschaft Addis Abeba-NGOs in Äthiopien (2018). 
https://addis-abeba.diplo.de/

Deutsches Auswärtige Amt: Äthiopien: Stand: October 2016 Website (2016). https://www.auswaertiges-amt.de/

Dickinson, E. (2009). Kagame: "Foreign aid on our terms: Writing in the Financial Times".

Erler, B. (1985). Tödliche Hilfe. Freiburg.

Ethiopian Broadcasting Corporation (2017). Addis Ababa: Ethiopian Broadcasting Corporation.

Foreign Aid Policy-China.org.cn (2011). www.china.org.cn/government/whitepaper/2011-04/21/content_22410897.htm

German Federal Foreign Office/Deutsches Auswärtige Amt (2013). Wirtschaft Äthiopiens. Report, Berlin: German Federal Foreign Office/Deutsches Auswärtige Amt.

Global Development Research Center (1999).

Gray, H. (2016). Is a Friend of "The Conversation" (Source): "How and Why China Became Africa's Biggest Aid Donor".

Guimei, Y. (2010). China and Africa: Mutual Benefit and Win-Win. Beijing: Guangming Daily.

Habasa, E. (2015). Impact of Foreign Aid on Economic Growth in Africa.

Hailemeskel, B. (2017). Ethiopia: Audit Gaps Surge, Parliament Condemns Itself. Addis Ababa: Addis Fortune.

Historpedia: Africa and Foreign Aid (2012). https://sites.google.com

Information Nigeria News Feed (2018). Africa Loses \$148 Billion to Corruption Annually-Report.

Jalata, G. G. (2014). Development Assistance from the South: Comparative Analysis of Chinese and Indian to Ethiopia. Chinese Studie-Scientific Research Publishing, 3, 15. https://doi.org/10.4236/chnstd.2014.31006

Jeffery, J. (2016). Ethiopia's Drought Response: Success or Anguish? African Businesses

Juma (2011). The Ethiopian Herald (p. 5).

Karanja, J. (1992). New African.

Lancaster, C. (2008). Foreign Aid: Diplomacy, Development, Domestic Politics. Chicago, IL: University of Chicago Press.

Matsilele, T. (2015).

McDoom, O. S. (2013).

https://unu.edu/publications/articles/to-aid-or-not-to-aid-the-case-of-rwanda.html

Moyo, D. (2009). Dead Aid. New York.

Polman, L. (2010). Die Mitleidsindustrie. Frankfurt am Main, New York.

Rosenberg, S. (2012). Moscow: BBC News.

Sanchez, M. (2016). Foreign Aid and Growth in Africa: A Case Study of Uganda.

Seitz, V. (2011). Afrika wird arm regiert oder wie man Afrika helfen kann. Originalausgabe 2009, Deutscher Taschenbuch Verlag München, 5., aktualisierte und erweiterte Auflage.

Shikwati, J. (2007). "Entwicklungshilfe in der Kritik"/"Development Aid in the Criticism". "n-tv" POLITIK", and in Internet

Sirleaf, E. J. (2012).

Slomka, M. (2010). ZDF-TV-Doku (German TV). 
Sudan Tribune (2012). Paris: Sudan Tribune.

Tankou, E. A. (2018). Addis Ababa: Head of Information Division, African Union Commission.

The Conversation Academic Rigour, \& Journalistic Flair (2016). How and Why China Became Africa's Biggest Aid Donor.

The Guardian (2012). USAID Covertly Influencing Political Processes, Says Russia. London: The Guardian.

Unmuessig, B. (2012). Shrinking Space for NGOS. Closure of the Heinrich Böll Foundation Office in Ethiopia.

WDR (2012). “West Art”“"Fatale Entwicklungshilfe für Afrika” als “Süßes Gift”.

Wiedemann, E. (2005). Helping the Hungry: Addicted to Aid in Ethiopia. Addis Ababa: Spiegel Online International.

World Bank (2012). Press Release, Washington: World Bank.

World Bank (2015). Report Says Ethiopia Is Poised to Become a Middle Income Country by 2025. Washington: World Bank.

Wüllenweber, W. (2011). Die Hilfsindustrie. Stern-Artikel. 